\title{
Article
}

\section{Stratigraphy of volcanic rock successions of the North Atlantic rifted margin: the offshore record of the Faroe-Shetland and Rockall basins}

\author{
David W. JOLLEY ${ }^{1 *}$ ๑, John M. MILLETT ${ }^{1,2}$, Nick SCHOFIELD ${ }^{1}$, \\ Lena BROADLEY ${ }^{1}$ and Malcolm J. HOLE ${ }^{1}$
}

\footnotetext{
${ }^{1}$ Department of Geology and Geophysics, School of Geosciences, University of Aberdeen, Aberdeen, UK.

${ }^{2}$ VBPR AS, Høienhald, Oslo, Norway.

*Corresponding author. Email: d.jolley@abdn.ac.uk
}

\begin{abstract}
The integration of biostratigraphical, wireline log, geophysical and available geochronological ages has identified two principal periods of volcanism in the Faroe-Shetland and Rockall basins. The first is pre-breakup, upper Danian to lower Thanetian: in the Rockall and Faroe-Shetland basins, isolated volcanic activity from $62 \mathrm{Ma}$ to $58.7 \mathrm{Ma}$ is identified in areas closely linked to the SSWNNE structural fabric of the continental margin. Volcanic activity was concentrated at basin flank fissures and localised point sources. This rift-flank volcanism led to widespread volcanic ash deposition, localised lava flow fields and the formation of igneous centres. Some of the Hebridean and onshore central complexes (e.g., Rum) were uplifted and rapidly eroded during the later pre-breakup period, while additional accommodation space was developed in the adjacent offshore basins. Onset and termination of pre-breakup volcanism is correlated to intra-plate stress regimes in Europe, following the cessation of convergence of Africa and Europe in the Danian. The second is syn-breakup, upper Thanetian to Ypresian, initiated at $c a .57 \mathrm{Ma}$ in the Rockall and Faroe-Shetland basins. Initial high-volume extrusive igneous successions were focussed to the $\mathrm{W}$ in the Faroe-Shetland Basin. In the centre and $\mathrm{E}$ of the FaroeShetland and Rockall basins, separate eruption loci developed along pre-existing lineaments either as fissure or point-sourced lava fields. Short-term cessation of eruption at $\sim 55.8 \mathrm{Ma}$ was followed by resumption of flood basalt eruptions and a shift in focus to the NW. Fluctuations in the syn-breakup eruption tempo are reflected in the formation and subsequent rejuvenation of prominent unconformities, only previously recognised as a single erosive event. The $\mathrm{W}$ and northward shift of eruption focus, and the eruption of mid ocean ridge basalt-type lavas in the syn-breakup period reflect the onset of lithospheric thinning in the nascent North Atlantic Rift prior to flooding of the rift and eruption of the widespread lower Ypresian Balder Formation tephras.
\end{abstract}

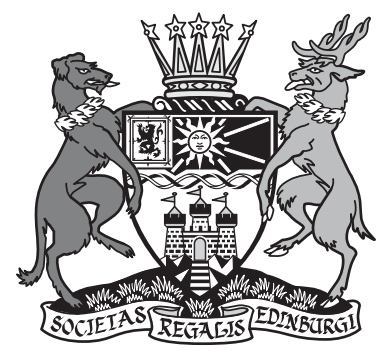

KEY WORDS: biostratigraphy, depositional sequences, Faroe-Shetland Basin, Palaeogene volcanism, Rockall Basin, volcanic ash, volcanism.

The Faroe-Shetland and Rockall basins (Fig. 1) contain a comprehensively studied sequence of marine and terrestrial Palaeogene sedimentary rocks, which have a well-defined stratigraphical framework (Ebdon et al. 1995; Ritchie et al. 2011; Stoker \& Varming 2011) and depositional palaeogeography. This stratigraphical framework has been derived from analysis of sedimentary rock successions to the E of the Faroe-Shetland escarpment, a feature which has been taken to mark the edge of the North Atlantic Igneous Province (NAIP) flood basalt lava field. To the Wof the FaroeShetland escarpment, thick sequences of extrusive basaltic lavas, hyaloclastites and volcaniclastic sedimentary rocks dominate the early Palaeogene basin fill (Schofield \& Jolley 2013). At the eastern margin of the Faroe-Shetland Escarpment, volcanic and volcaniclastic rocks interdigitate with siliciclastic sedimentary rock successions in the Flett and Judd sub-basins (Fig. 1). Associated with these volcanic rocks is an extensive intrusive complex - the Faroe-Shetland Sill Complex (FSSC) - which extends into the central and eastern parts of the Faroe-Shetland Basin (FSB; Rateau et al. 2013; Schofield et al. 2015).

Occurrences of tephras or 'tuff' layers, interpreted to originate as volcanic ash airfall deposits (Knox \& Morton 1988), are more widespread than the associated lava fields. These tephra are recognised within the FSB and are correlative with ashes recorded in the Rockall, North Sea and Anglo-Paris basins (Knox \& Morton 1988; Ellison et al. 1994). The tephra record of the North Sea Basin was divided into two periods, termed by Knox \& Morton (1988) as Phase 1 and Phase 2 (the latter with four subdivisions). A recent review of tuffs within the

(C) The Author(s), 2021. Published by Cambridge University Press on behalf of The Royal Society of Edinburgh. This is an Open Access article, distributed under the terms of the Creative Commons Attribution-NonCommercial-ShareAlike licence (http://creativecommons.org/licenses/by-nc-sa/4.0/), which permits non-commercial reuse, distribution, and reproduction in any medium, provided the same Creative Commons licence is included and the original work is properly cited. The written permission of Cambridge University Press must be obtained for commercial re-use. doi:10.1017/S1755691021000037 


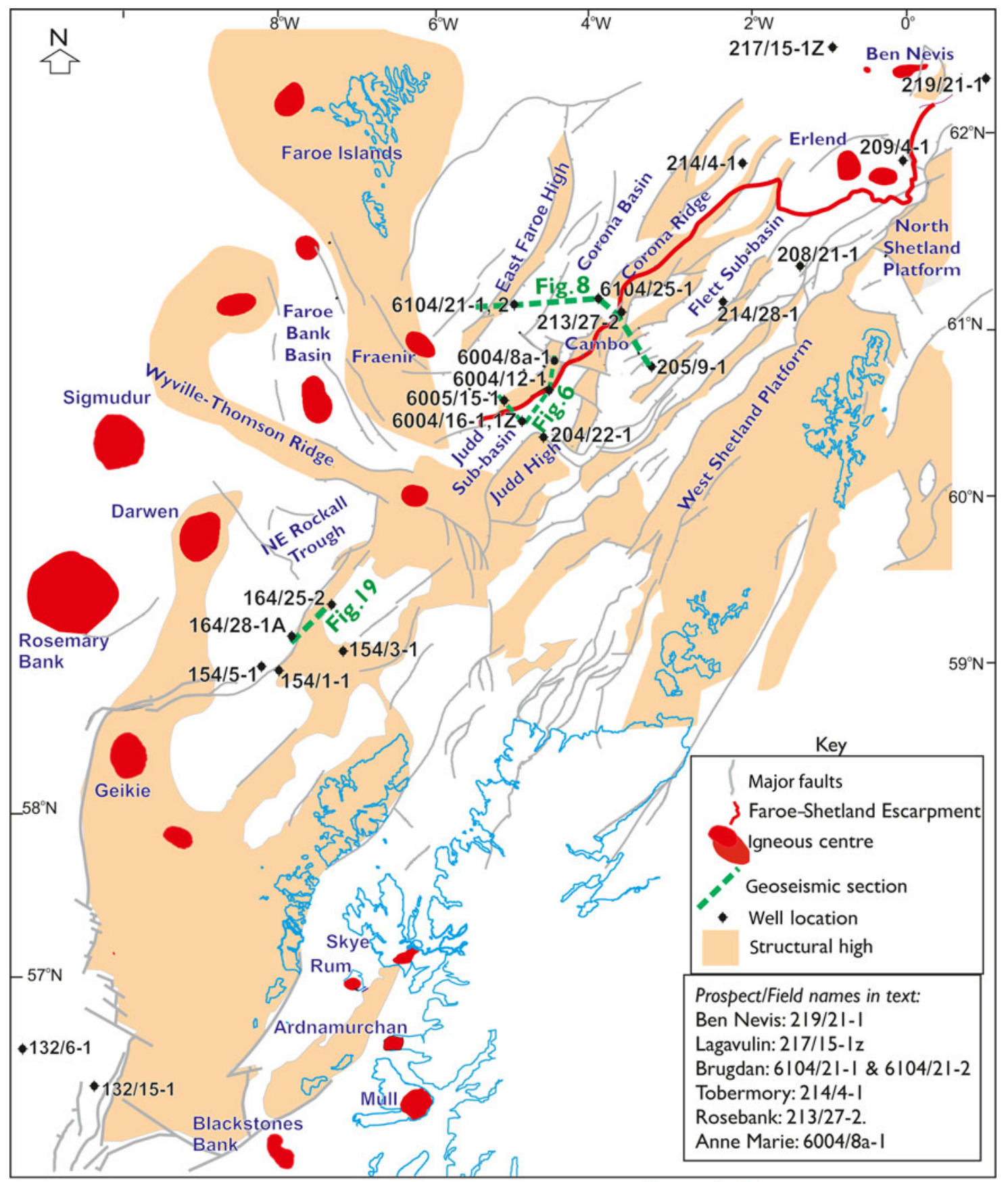

Figure 1 Location map for Rockall and Faroe-Shetland basins. Structural elements adapted from Ellis et al. (2009). Location of wells discussed in the text are shown with structural and other significant geological features.

FSB (Watson et al. 2017) confirmed the occurrence of these two well-developed tephra phases and extended the onset of the oldest tephra deposits from the Thanetian to the upper Danian.

Constraining the stratigraphical distribution of volcanic and volcaniclastic rocks in the Faroe-Shetland and Rockall basins is fundamental to the understanding of this part of the NE Atlantic margin. Despite this, interpretations of the stratigraphy and distribution of these volcanic rocks have remained ambiguous, both within the basins and within marginal onshore exposed successions such as on the Faroe Islands, East Greenland and the British Palaeogene Igneous Province (BPIP). The stratigraphical relationship of the Faroe Islands Basalt Group (FIBG; Passey \& Jolley 2009) to the sedimentary and volcanic rocks of the FSB has been subject to diverging interpretations. These are rooted in the differing stratigraphies, which propose eruptions over a short period between 57.2 Ma and 54.4 Ma (Thanetian-Ypresian; Passey \& Jolley 2009; Schofield \& Jolley 2013; Ellis \&
Stoker 2014), or a longer duration from $\sim 61.5 \mathrm{Ma}$ to $54.4 \mathrm{Ma}$ (Selandian-Ypresian; Waagstein et al. 2002; Mudge 2015; Stoker et al. 2017; Olavsdottir et al. 2019).

Peak extrusive volcanism during the eruption of the FIBG has been linked to uplift and erosion of the southern part of the FSB, leading to the formation of an unconformity. Subsurface mapping has revealed a dendritic drainage system incised into older shelf marine rocks within the Judd Sub-basin (Fig. 1; e.g., Hartley et al. 2011), with the surface being marked by a shift from marine to terrestrial sedimentation (Mudge 2015). Termed the Flett Unconformity, this feature has been related to maximum thermal support from the Iceland mantle plume prior to the onset of sea floor spreading (Smallwood \& Gill 2002; Shaw Champion et al. 2008; Hartley et al. 2011; Mudge 2015). However, other authors suggest that this uplift and subsidence can be explained by plate tectonic forces alone (e.g., Stoker et al. 2017). 
Improvements in sub-basalt geophysical data acquisition and interpretation, allied to an increase in well penetrations, has given new insight into the subsurface stratigraphy within and below the area of thick flood basalts W of the Faroe-Shetland escarpment (Gallagher \& Drumgoole 2007; Jerram et al. 2009; Wright et al. 2012; Schofield \& Jolley 2013; McLean et al. 2017). In particular, these data and interpretations, such as that of Watson et al. (2017), have provided the basis for a revised understanding of the relationship between the volcaniclastic sedimentary rock units and the extensive flood basalt successions (e.g., Naylor et al 1999; Archer et al. 2005; Millett et al. 2016) within the FSB and Rockall Basin. In particular, the subsurface well and seismic data archive has yielded a record of NAIP volcanism in the context of a $>6 \mathrm{Myr}$ marine basin sedimentary rock record. As this subsurface record is considerably thicker than that preserved in the onshore margins of the NAIP, understanding the stratigraphy and variations in depositional environments of basinal volcano-sedimentary successions has enabled stratigraphical insights into the rifting of the NE Atlantic.

\section{FSB pyroclastic and extrusive volcanic record}

The main phase of extrusive activity in the NAIP is recorded in the FSB by the extrusion of $40,000 \mathrm{~km}^{2}$ of flood basalt lavas (Passey \& Jolley 2009), which thin from the $>6 \mathrm{~km}$ thickness of the FIBG eastwards to a few metres at the edge of the Faroe-Shetland Escarpment. These thick flood basalts have represented a significant challenge to the seismic imaging of intra and sub-basalt strata (e.g., Gallagher \& Drumgoole 2007). Despite improvements in sub-basalt geophysical imaging, the difficulties of deepwater exploration including drilling challenges (Millett et al. 2016; Watson et al. 2017) and the presence of basaltic sill complexes in the sub-basalt sedimentary rock sequences (Schofield et al. 2015) have held back exploration to date. In consequence, wells drilled to the E of the Faroe-Shetland Escarpment significantly outnumber those drilled through the thicker flood basalt cover.

The most extensive and youngest of the lava flow fields in the FSB are made up of the FIBG in the W (Passey \& Jolley 2009), the exposed part of which is broadly correlative with largely unnamed flow fields on the Corona Ridge and to the NE (Jerram et al. 2009; Wright et al. 2012; Schofield \& Jolley 2013; Millett et al. 2017; Hardman et al. 2018). Separate monogenetic volcanic centres and associated lava fields in the FSB have been recognised to predate the extensive flood basalt eruptions (Jolley 2009; McLean et al. 2017). The extent, stratigraphy, eruption history and depositional environments of volcanic rocks in the FSB have been interpreted from integrated seismic-borehole studies based on industry seismic and well data in the offshore regions (Jolley \& Bell 2002; Jolley 2009; Passey \& Jolley 2009; Ellis \& Stoker 2014). Recently, pre-breakup, syn-breakup and postbreakup tectonic phases have been proposed for the FSB (Stoker et al. 2017), and are used here. However, the stratigraphical relationship of the volcanic successions to the sedimentary rock succession in the FSB remains unclear.

\subsection{Methods}

Understanding of the geology of the volcanic rocks in the FaroeShetland and Rockall basins has been aided by data from hydrocarbon exploration within the basin, the stratigraphy having been interpreted from geophysical data and well penetrations. Within wells, stratigraphy has been derived from proprietary microfossil, nannofossil and palynological zonations, which are held to be confidential and, as such, are not used in this analysis. To constrain the strata examined here, we have conducted extensive palynological analysis of well sections and derived a stratigraphical model (Fig. 2) based on the Geomagnetic Polarity Time Scale (GPTS) 2012 and later update (Gradstein et al. 2012; Ogg et al.
2016). In addition to the palynostratigraphy utilised in Ogg et al. (2016), which is derived from Powell (1992), additional datums derived from Ebdon et al. (1995), Jolley et al. (2005), Jolley \& Morton (2007) and Schofield \& Jolley (2013) have been included. The palynostratigraphy utilised here is closely similar to published records from the North Sea Basin, where data are more widely available (e.g., Knox \& Holloway 1992; Schroder 1992; Jolley 1998; Kender et al. 2012), although there are differences in detail. Selected stratigraphically significant species of microplankton and pollen/spores are presented in data plots for the studied well sections. Where appropriate, sum pollen/spore and sum microplankton data are plotted as raw data from standardised preparations. These data are of value in identifying flooding events and constraints on the stratigraphical analysis. Species data are presented as percentages of either microplankton or pollen/spores, as appropriate. In sections where the total counts are highly variable, the data are plotted as square roots to eliminate misleading frequency plots.

The sequence stratigraphical framework erected for the FSB by Ebdon et al. (1995) is relatable to the palynostratigraphy used here. Biostratigraphical datums derived from palynomorphs and foraminifera were used by Ebdon et al. (1995) to constrain the ages of their unconformity bounded sequences, following the original sequence stratigraphical concept of Posamentier \& Vail (1988). This approach has the advantage of emphasising the succession of strata in chronostratigraphically-related sequences. In contrast, a lithostratigraphical approach to basin stratigraphy has inherent pitfalls from diachronous facies.

Wireline data from wells were used in order to appraise the volcanic lithologies encountered within the study wells. A simplified facies scheme is used based on the principles of volcanic wireline analyses (e.g., Planke 1994; Nelson et al. 2009; Millett et al. 2016). The main interpreted volcanic facies include simple lava, compound lava, hyaloclastite, intrusions, volcaniclastic lithologies and tuffs. No volcanic cuttings analyses (e.g., Millett et al. 2014) were undertaken during the current study and so the volcanic lithologies are assigned based on an appraisal of the originally reported wellsite lithologies coupled to an appraisal of the log character.

The stratigraphy used in this study is, where appropriate, compared to radiometric dating of igneous lithologies from the BPIP, published by other authors. It is fortunate that Wilkinson et al. (2017) has undertaken an assessment of published NAIP radiometric data. The assessment considered the statistical validity of published radiometric dates, recalculating them based on the new standards of Gradstein et al. (2012). These valid ages are considered below and those rejected by Wilkinson et al. (2017) are not used. Valid ages with experimental errors of $>0.5 \mathrm{Myr}$ are generally not included here, because of the short duration of stratigraphical events. Exceptions are made where no alternative is available. Ages that have no published analytical details are not included - for instance, the radiometric dates for the Skye Western Red Hills Complex and the Ardnamurchan Central Complex (see Emeleus \& Bell 2005). Following this approach has meant that some BPIP igneous complexes currently lack valid, published radiometric dates.

The stratigraphy used can be applied to lava flow fields where they include volcaniclastic and siliciclastic sedimentary rock interbeds. While dinocysts and other algae are of stratigraphical value in marine facies, lava field and transitional depositional environments require a combination of this approach with the analysis of pollen and spores derived from higher plants. Pollen and spores dominate terrestrial successions, but are transported in abundance into coeval brackish to fully marine environments. Transportation into the transitional coastal zone was dominated by fluvial taphonomic processes (e.g., Peck 1973). Further transportation of palynofloras into the marine basin was by turbidity currents amplified by the rafting of palynomorphs offshore on 


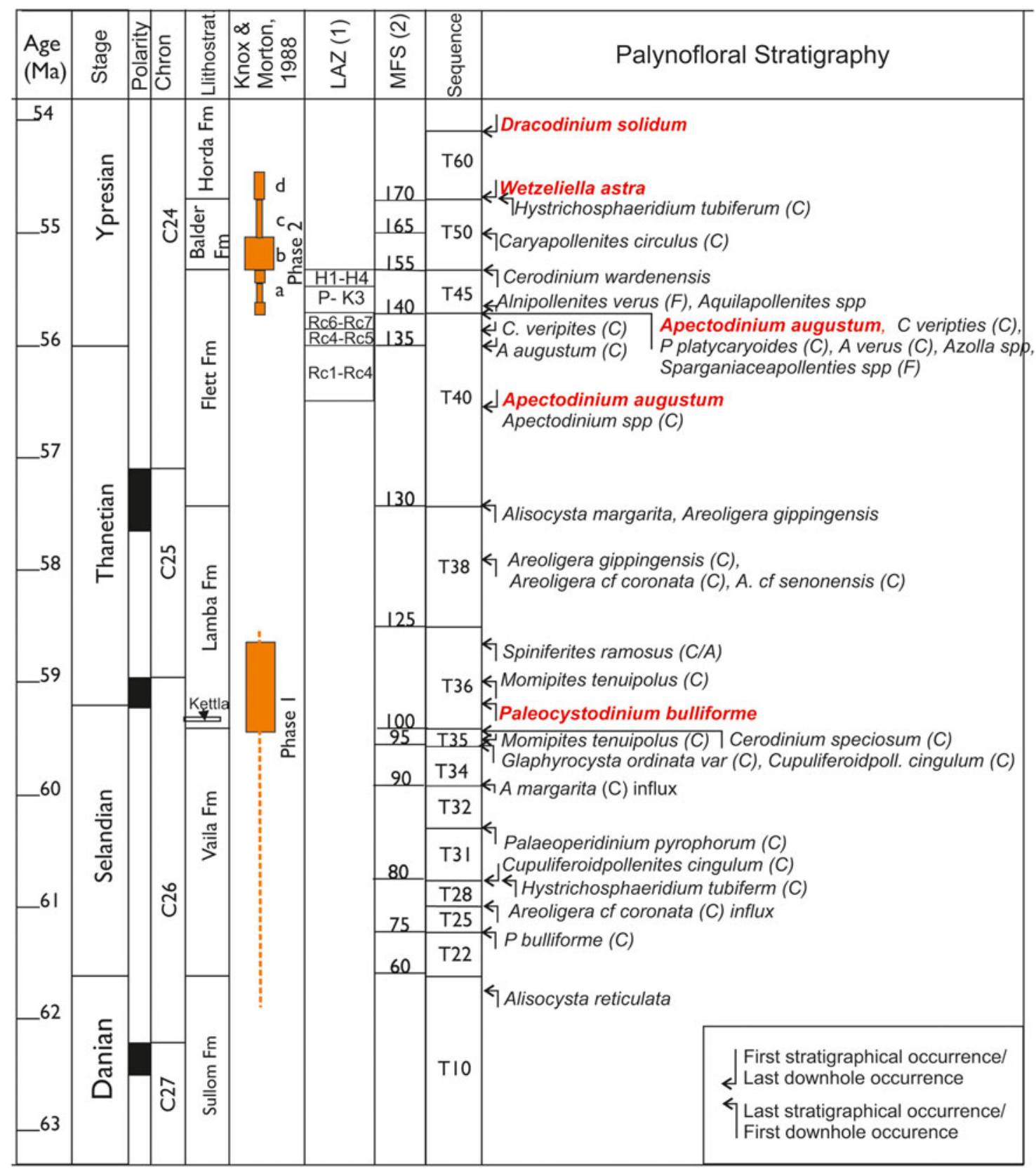

Figure 2 Stratigraphical model based on GPTS 2012 and 2016 (Gradstein et al. 2012; Ogg et al. 2016). Dinocyst datums in bold red are derived from the GPTS 2016; other dinocyst and pollen/spore records are derived from Ebdon et al. (1995) or from regional studies of microplankton distribution (e.g., Mudge \& Bujak 2001; Jolley et al. 2005). Because of the absence of magnetostratigraphical data for the subsurface FSB, the magnetochrons are positioned with reference to correlative palynological events in the wider North Sea Basin (Ali \& Jolley 1996; Jolley 1998). Phase 1 and Phase 2 North Sea Basin pyroclastic events (Knox \& Morton 1988) are shown relative to the stratigraphy of the FSB. Sequences are those of Ebdon et al. (1995). Abbreviations: LAZ = local assemblage zone (defined by Schofield \& Jolley 2013); MFS = maximum flooding surfaces (defined by Jolley \& Morton 2007). Sequences T10 to T60 are those defined by Ebdon et al. (1995) for the FSB.

density layers during periods of marine water stratification (e.g., Jolley \& Morton 2007). Integration of marine and terrestrial records has consequently allowed correlation across depositional facies.

The samples used in this study were derived from subsurface wells, from which ditch cuttings are the dominant sample type, with some sidewall and conventional core pieces included where available. Because of the potential for downhole cavings in ditch cuttings, the stratigraphy used is primarily based on first downhole occurrences, which mark regional or wider disappearances of species from the stratigraphical record.

Samples for palynological analysis were processed following standard techniques, including hydrofluoric acid digestion, boiling in $20 \%$ hydrochloric acid to remove precipitates and oxidation for $5 \mathrm{~min}$ in dilute $40 \%$ nitric acid where necessary. The resultant residues were mounted in a permanent petropoxy mounting medium and examined under a transmitted light Olympus BX53 microscope. For each sample, counts of 250 specimens were targeted and the data normalised as percentages of the marine or terrestrial palynoflora. Where full counts were not attained, data were expressed as square roots.

Samples collected for palynology were also analysed for major element geochemistry. In analysing the geochemistry of the sedimentary rocks studied here, two principle techniques were used. Standard X-ray fluorescence (XRF) techniques have been used to analyse the full range of major oxides. Because of the time taken in preparing samples for XRF analysis, and the number of samples for analysis, other samples were subjected to Flame Atomic Absorption Spectrometry (FAAS). These techniques were used and cross-correlated on Columbia River Basalt Province intra-lava 
field samples by Jolley et al. (2008; and see supplementary material S1 available at https://doi.org/10.1017/S1755691021000037).

The primary purpose of collecting XRF and FAAS data was to allow identification of ashfall events and consequent elevated marine macronutrient levels (eutrophication events) in drill cuttings. To allow comparison between major element distribution and the dinocyst record, XRF and FAAS were conducted on the palynological sample set. The stratigraphical distribution of ashfall events in the FSB was recorded by Watson et al. (2017), which included some of the same wells analysed here. Plotting of phosphorous pentoxide $\left(\mathrm{P}_{2} \mathrm{O}_{5}\right)$ :aluminium oxide $\left(\mathrm{Al}_{2} \mathrm{O}_{3}\right)$ ratios for key wells was done to identify intervals of elevated nutrient input, moderated against variations in clay input from clastic sources. Gonyaulacoid, autotrophic dinoflagellates can bloom in response to water mass eutrophication, where levels of iron, phosphorus and nitrogen are elevated. Other algae (e.g., diatoms) bloom in response to water mass eutrophication in a similar way, the increase in these prey organisms leading to small-scale blooms of predatory autotrophic dinoflagellates. The palynological data presented here include influxes of taxa, which can be interpreted as eutrophication-driven bloom events. Comparison of these records to major element data allows the identification of increases in macronutrient availability, which is potentially linked to volcanic events.

\section{Pre-breakup volcanic activity}

Isolated ash deposits have been reported from the periphery of the NAIP (e.g., Svalbard; Jones et al. 2017) and the W of Britain (e.g., Ganerød et al. 2010), and are attributable to the earliest phase of volcanism beginning in the latest Danian around ca.62 Ma (e.g., Saunders et al. 1997; Wilkinson et al. 2017). Early ashes are felsic in character (rhyolitic) and their distribution is limited in the offshore basins (e.g., Watson et al. 2017). Unlike basaltic ashes, the formation of felsic ashes does not necessarily require major flooding events to promote fragmentation, which contributes to the more limited distribution of the felsic ashes offshore.

In a recent review of pyroclastic deposits of the FSB, Watson et al. (2017) noted the occurrence of volcanic ash in marine sedimentary rocks through the Selandian. In particular, tuffaceous units were noted in the upper Selandian, while older Selandian and upper Danian (sequences T10 to T28) records were dismissed as misinterpretations on the basis of a review of petrophysical data (Fig. 2). Wells 6005/15-1, 6004/12-1 and 6004/ 16-1 were drilled the Danian to Ypresian succession of the Judd Sub-basin, Selandian to Thanetian tephras being noted in $6005 / 15-1$ by Watson et al. (2017). $\mathrm{P}_{2} \mathrm{O}_{5}: \mathrm{Al}_{2} \mathrm{O}_{3}$ in shaledominated ditch cutting samples from well 6005/15-1 (Fig. 3) show a series of high-value peaks in the Selandian to Ypresian. One of the most prominent of these $\mathrm{P}_{2} \mathrm{O}_{5}: \mathrm{Al}_{2} \mathrm{O}_{3}$ peaks is recorded at the Sequence T36 volcaniclastic Kettla Tuff $\mathrm{Mb}$ (Fig. 3; and see Watson et al. 2017). Importantly, the correlation of the $\mathrm{P}_{2} \mathrm{O}_{5}: \mathrm{Al}_{2} \mathrm{O}_{3}$ peak to the Kettla Tuff $\mathrm{Mb}$ indicates that similar peaks in the Selandian to Thanetian interval of all three wells mark basin ashfall events within Selandian sequences T22-T36 (Figs 3-5; supplementary data S1).

Evidence for ashfall events in the latest Danian of the FSB were not supported by Watson et al. (2017), who focussed on interpretations made in Naylor et al. (1999), linked to wells nearby the Judd and Westray igneous centres. These centres were subsequently identified as being Palaeozoic and Precambrian intrusive rocks. Occurrences of volcaniclastic material in Sequence T22 was noted by Watson et al. (2017), an observation supported here from major element analysis, also from well 6004/ 16-1z (Fig. 4). A comparable record of tephra was recorded at $22.7 \mathrm{~m}$ below surface by Morton et al. (1988) from a shallow
British Geological Survey borehole (82/12) drilled in the Papa Basin. The original palynological analysis attributed a Danian age to the single tephra horizon recorded; re-examination here of the palynofloras from core samples recovered abundant Palaeoperidinium pyrophorum, common specimens of Palaeocystodinium bulliforme and Isalbelladinium? viborgense from 22.70 $\mathrm{m}$. These occurrences indicate an age equivalent to Sequence T22 (Fig. 2). In contrast to the Sequence T22 tephra recovered from well 6004/16-1z, which is of andesitic composition (Watson et al. 2017), Morton et al. (1988) reported that the 82/12 tephra was tholeiitic, supporting multiple small-scale sources for these lower Selandian volcanics.

Geochemical analysis of cuttings from the Danian was not undertaken. However, examination of fresh ditch cuttings from well 6004/16-1z indicated that traces of tephra were visible within the Sequence T10 sediments, although this is not detectable petrophysically (Watson et al. 2017). The older Danian record of volcanism in the FSB remains equivocal. This is due to the low frequency of well penetrations of the deeper Palaeocene, and to the difficulties in identifying isolated tephras in ditch cuttings without supporting geochemical analyses.

Major element analysis of Judd Sub-basin wells has identified occurrences of tephra in Selandian sequences T32, T34 and T35 (Figs 2-5). These tephra predate the prominent Kettla Tuff Mb, which occurs in Sequence T36. Interpretation of geophysical data illustrates that these tephra horizons are correlative (Figs 3-7), with the greatest concentration in sequences T34 T35. A notable aspect of the Selandian tephra record is the absence of any tephra events in the interval within Sequence T25 to Sequence T31. Previous records of tephra from sequences T25 and T28 (Sørensen 2003; Stoker \& Varming 2011) have already been disputed by Watson et al. (2017) on petrophysical grounds. The major element analysis here does not support the occurrence of tephra in this interval, or in overlying Sequence T31.

The source of these Selandian tephras has been subject to some debate, rooted in difficulties in correlating their thin, discontinuous record. They are considered unlikely to have been sourced from the BPIP onshore volcanic centres (Morton et al. 1988; Watson et al. 2017), because the high-titanium tholeiitic geochemistry of the tephras has few comparable sources in the onshore record. Taken together with the timing of the FIBG eruption (Morton et al. 1988; Jolley \& Bell 2002; Passey \& Jolley 2009; Ellis \& Stoker 2014), this has been used to suggest an undetermined NE Atlantic source. On the East Faroe High (Fig. 1), well 6104/21-2 penetrated around $30 \mathrm{~m}$ of heavily sill-intruded, quartz-free volcaniclastic sandstone within Sequence T35 (Fig. 8). These sedimentary rocks were reported by Watson et al. (2017) to contain a terrestrial palynoflora of the 'westerly sourced' type of Jolley \& Morton (2007), leading them to suggest a derivation from the WSW originating in the Munkegrunnar Volcanic Province, in particular the Fraenir Volcanic Centre (Fig. 1). While this is a possible source, interpretation of seismic data for this study (Fig. 9) has indicated the presence of a thick package of currently undrilled volcanic or volcaniclastic rocks to the NW of the East Faroe High, which appears to be within the interval sequence T31-T36. The presence of this unit points to an unrecognised pre-breakup extrusive volcanic succession underlying the exposed FIBG.

\subsection{Kettla Tuff Mb, Sequence T36}

In contrast to the limited extent of the tephra units of sequences T10-T35, the Kettla Tuff Mb is widespread and readily identified from wireline log and lithological data, being composed of mixed siliciclastic and volcaniclastic sediment (Eidesgaard \& Ziska 2015). In contrast to the majority of the tephras reported from younger sequences T40 to T50, Watson et al. (2017) 


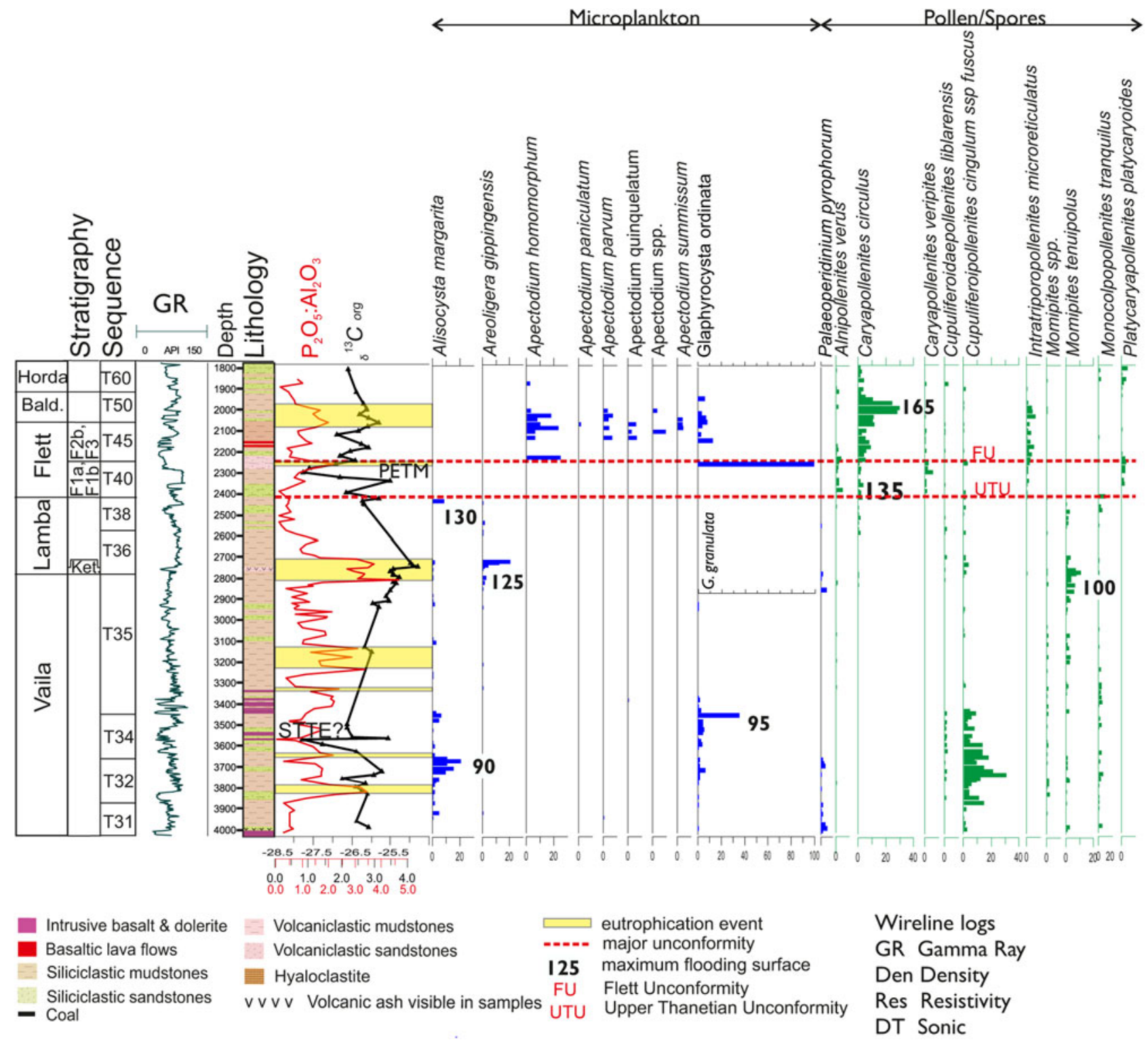

Figure 3 Well 6005/15-1: this well penetrated two thin syn-breakup basalt flows with an interbedded sedimentary unit, which yielded a palynoflora diagnostic of Sequence T45 (see Jolley 2009). The top of Sequence T40 is truncated by the Flett Unconformity, and Flett Formation strata below MFS 135 are missing, resting unconformably on the Lamba Formation (see Fig. 1 for lithostratigraphy used). Sequences T38 to T36 marine sedimentary rocks are marked by occurrences of Alisocysta margarita and Areoligera gippingensis in the Lamba Formation. At the base of Sequence T36, the Kettla Tuff $\mathrm{Mb}$ is recognised from its $\log$ signature and from the $\mathrm{P}_{2} \mathrm{O}_{5}: \mathrm{Al}_{2} \mathrm{O}_{3}$ plot, derived from FAAS of ditch cutting samples. This ratio highlights tephra-rich intervals in older Selandian sedimentary rocks, although these do not correspond directly to the cored interval of tuffaceous sediment (3508-3514 m; see Watson et al. 2017) because of ditch cuttings sample spacing. The $\delta^{13}$ Corg record was derived from kerogen preparations. The upper part of the PETM record is missing at the Flett Unconformity. An older carbon isotope excursion is potentially a record of the STTE. All taxon palynomorph data displayed as percentages of total terrestrial or marine groups; only stratigraphically significant taxa are displayed. The standardised count of microplankton is plotted in this and subsequent figures to illustrate intervals of maximum marine influence. The key is common to all well stratigraphy figures and all wells are displayed in measured depths in metres (i.e., the depth in the well bore below a rig datum, usually the rotary table).

reported that the Kettla Tuff $\mathrm{Mb}$ and older tephras were of andesitic composition. Because the Kettla Tuff Mb is generally identified from its double-peak gamma-log response (Knox \& Holloway 1992; Watson et al. 2017) and the constraints enforced by the lack of cored examples, the Kettla Tuff Mb thickness is probably underestimated. For example, within well 6005/15-1 a thick sequence of shelf marine Lamba Formation sedimentary rocks (Fig. 3) includes a prominent volcaniclastic sandstone assigned to the Kettla Tuff Mb (Jolley 2009; Watson et al. 2017). Major element ratios from ditch cutting samples in this well indicate that eutrophication continued after the uppermost gamma-log evidence (Fig. 3). As with the older sequence T32T35 tephras, ashfall-driven eutrophication led to autotrophic dinoflagellate blooms, in this case yielding abundant Areoligera gippingensis dinocysts (Fig. 3).
Kettla Tuff Mb successions in the majority of Flett Sub-basin wells (e.g., 214/27a-3 and 214/28-1) are comparable to those of the Judd Sub-basin, being composed of volcaniclastic sandstone within otherwise marine sedimentary rocks. However, the Kettla Tuff Mb in Flett Sub-basin well 205/09-1 (Fig. 10) is interpreted by Watson et al. (2017) as a debrite. Cores from this well recovered Kettla Tuff $\mathrm{Mb}$ volcanic lithoclasts, indicating a local source.

The East Faroe High Brugdan prospect wells 6104/21-1 and 6104/21-2 drilled through the base of the eastern FIBG basalt sequence, before being abandoned in heavily sill-intruded shelf marine sediments of the Lamba and Vaila formations (Figs 8, 9). The shallowest sub-FIBG strata is attributable to the Lamba Formation and yielded the marine dinocysts Alisocysta margarita and Ar. gippingensis, whose youngest 


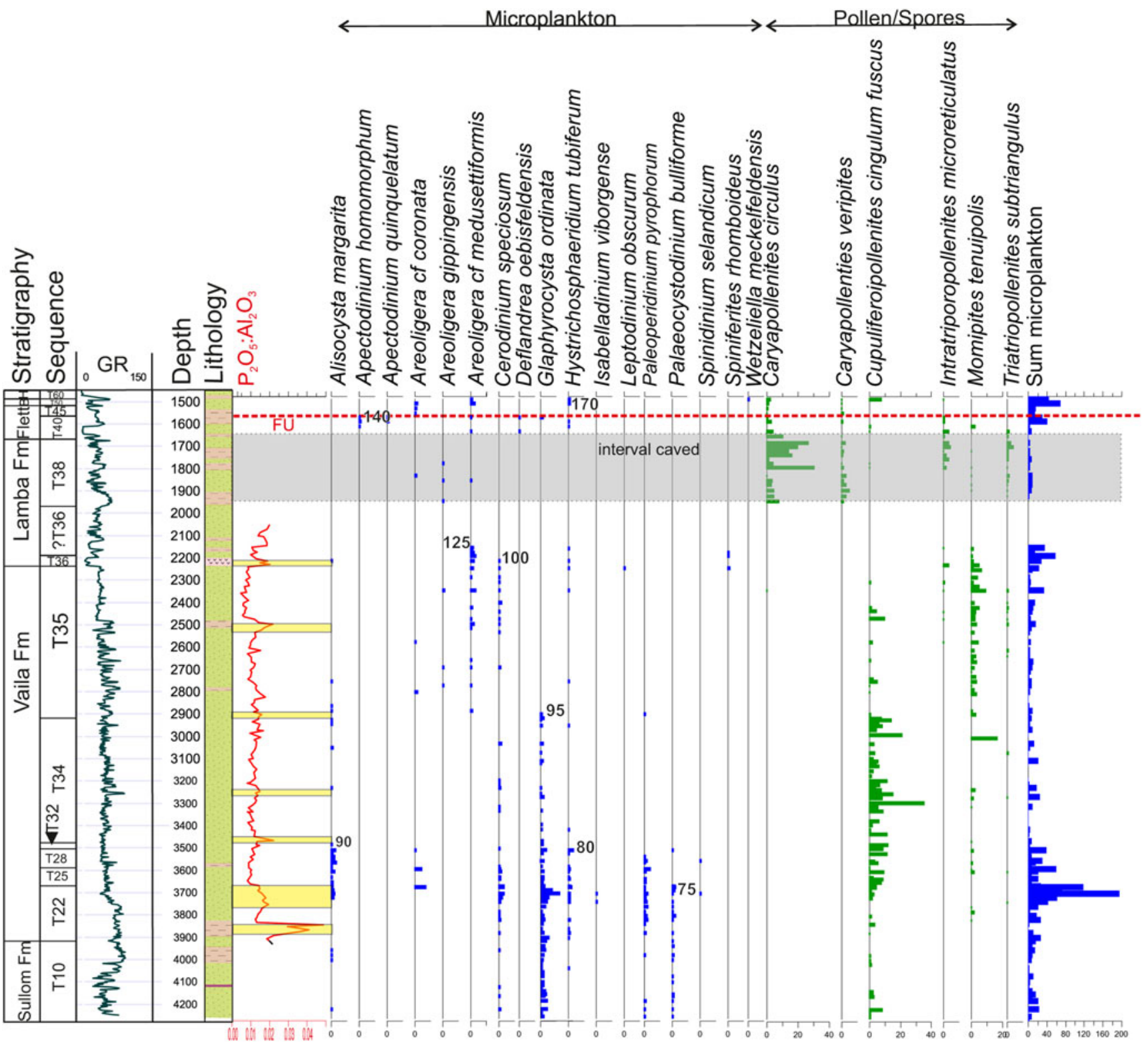

Figure 4 6004/16-1 Marjun: although the Flett Unconformity is identified by the absence of oldest Sequence T45 strata, cavings and potential confusion over drilling returns affect sample quality downhole to within Sequence T38. Below this, this deep well has a record of pre-breakup volcanism extending down into Sequence T22 and potentially Sequence T10. $\mathrm{P}_{2} \mathrm{O}_{5}: \mathrm{Al}_{2} \mathrm{O}_{3}$ identify tephra in sequence T22, T32-T36. All palynomorph data displayed as square roots; only stratigraphically significant taxa are displayed.

stratigraphical occurrence marks the top of the Lamba Formation/Sequence T38 across the FSB and its correlative equivalent in the North Sea Basin (Ebdon et al. 1995; Mudge \& Bujak 2001). Subsequent influxes of Areoligera cf. coronata, Spiniferites ramosus ramosus and Momipites tenuipolus confirm the extent of the Lamba Formation.

As with many other sub-lava field sedimentary rock sequences (Schofield et al. 2015; Angkasa et al. 2017), those of the Brugdan prospect area are intruded by numerous basaltic sills, identifiable from wireline log data by their high velocity, low gamma and sharp upper and lower margins, often resulting in box-like log profiles (e.g., Planke et al. 1999; Figs 8, 11). These intrusions were emplaced into marine claystones, which include the volcaniclastic sandstones of the Kettla Tuff Mb (Fig. 8), which reaches $>10 \mathrm{~m}$ thickness based on wireline log response. The palynoflora associated with the lower Sequence T36 interval containing the Kettla Tuff Mb in well 6104/21-2 is of shallow marine shelf composition, which, taken together with the well location being outside the depocentres proposed for the Kettla Tuff Mb by Watson et al. (2017), again supports a more localised source.
Further sources on the Corona Ridge were proposed as the origin of the volcaniclastic and tuffaceous elements of the local Kettla Tuff Mb (Eidesgaard \& Ziska 2015), although this was questioned by Watson et al. (2017) on the basis of the lack of volcanic rock penetrations of Thanetian age on the Corona Ridge and failure to identify a source on seismic data. However, multiple sources were favoured by Watson et al. (2017) to explain variable thickness of the Kettla Tuff $\mathrm{Mb}$ in each of the three depocentres they proposed for the FSB. These depocentres do not in themselves provide evidence for multiple eruptive centres for the Kettla Tuff Mb. Their location correlates with three of the four main sedimentary provenance zones (Fig. 12) of Jolley \& Morton (2007), representing sedimentary basins into which both direct and remobilised ash would have been accumulated.

\subsection{Extrusive volcanism of Sequence T36}

Alongside the Kettla Tuff $\mathrm{Mb}$ record of pyroclastic volcanic eruptions in the earliest Thanetian sedimentary rocks of the $\mathrm{FSB}$, are relatively small subsurface lava fields of the same age. 


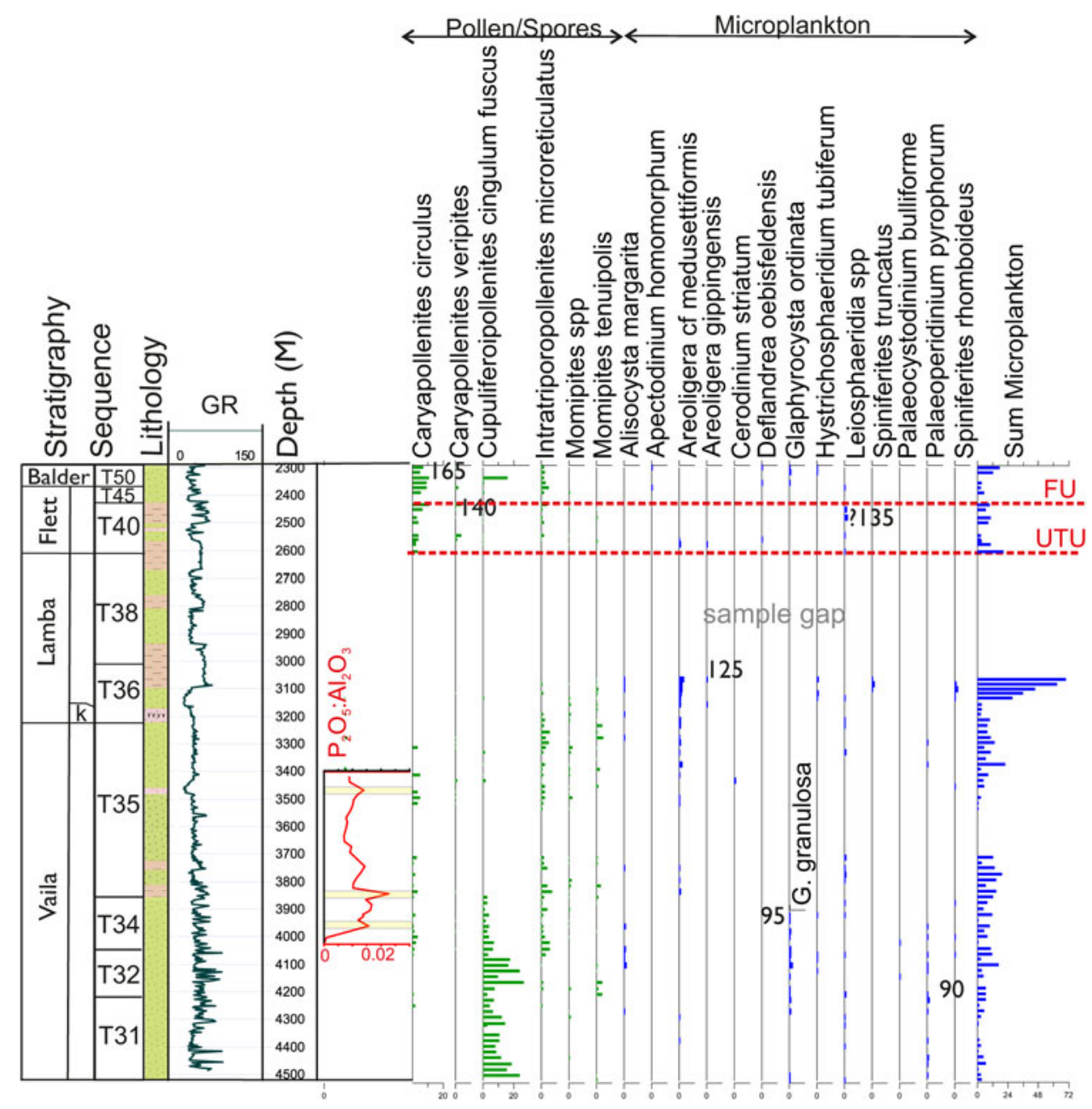

Figure 5 6004/12-1 Svinoy: no extrusive volcanics were present in this well other than the dispersed ash of the Kettla Tuff Mb and those identified from major element ratios. These data were derived from XRF analysis of ditch cutting samples (supplementary data $\mathrm{S} 1$ ), the $\mathrm{P}_{2} \mathrm{O}_{5}: \mathrm{Al}_{2} \mathrm{O}_{3}$ highlighting the presence of tephra in sequences T35 and T34, which are correlative with those recorded in 6005/15-1. Both the Flett Unconformity and the Upper Thanetian Unconformity are present in the well, with oldest Sequence T40 and oldest Sequence T45 strata being absent. All palynomorph data displayed as square roots; only stratigraphically significant taxa are displayed.

In the $\mathrm{N}$ of the FSB, well analysis and seismic interpretation of the Lagavulin prospect area (Fig. 1) recorded an extensive, syn-breakup lava field (Millett et al. 2016). Penetrated by well 217/15-1Z, subsequent analysis of geophysical and biostratigraphical data (Jolley 2009; McLean et al. 2017) demonstrated that this lava field onlapped onto an uplifted and eroded upper Selandian to lower Thanetian (Sequence T36) lava field, previously drilled by Ben Nevis prospect well 219/21-1 (Fig 1). Although the size of the lava field has not been fully assessed to date (McLean et al. 2017), increased sub-volcanic temperatures (based on vitrinite reflectance; Rohrman 2007) have been inferred to relate to the intrusion of a deep-seated laccolith of the order of 10 's $\mathrm{km}$ in width. This intrusion is suggested to have influenced the apparent asymmetry of the Ben Nevis edifice, which was a potential source of the Kettla Tuff $\mathrm{Mb}$ in the N of the FSB (northern depocentre of Watson et al. 2017; Fig. 12).

Further evidence of a small, localised source for some of the lower Thanetian Kettla Tuff $\mathrm{Mb}$ volcaniclastic rocks was presented by Schofield et al. (2015), following the identification of a small subaerial lava field penetrated in Flett Sub-basin well 208/21-1 (Fig. 1). Sourced from fissures along the crest of a tilted fault block, the lava field extends for $<10 \mathrm{~km}$ downdip. As with the coeval Ben Nevis lava field, an extensive FSSC magma plumbing system occurred beneath the extruded volcanics. A third example of a Sequence T36 extrusive lava field has been recorded in Corona Ridge well 6004/8a-1 (Figs 1, 6). Resting on Selandian marine siliciclastic sediments, lava flows are succeeded and interbedded with volcaniclastic sediment deposited in a shallow marine environment. The ditch cuttings recovered from this well were of poor quality, with pervasive cavings, limiting further stratigraphical interpretation and inhibiting a robust environmental interpretation.

There are currently no convincing records of extrusive volcanic rocks or tephra in Thanetian upper Sequence T36 and Sequence T38. A report of a Sequence T38 tuff in well 204/221 by Watson et al. (2017) identified a potentially thick volcaniclastic sandstone unit stratigraphically younger than other Lamba Formation records. The age of this unit was defined by biostratigraphy available at the time, which gave a range equal to sequences T36-T40. This was supported by the interpretation of the Sequence T36 upper surface from seismic data. New palynological data from wells $204 / 22-1$ and 204/22-2 allied to wireline responses and seismic interpretation shows that the volcaniclastic sandstone forms part of an expanded Sequence T36 succession, composed of seaward dipping clinoforms. Palynofloras from this interval are characterised by a dominance of transported shallow marine and terrestrial taxa. The Kettla Tuff $\mathrm{Mb}$ and overlying prograding marine sediments that comprise Sequence T36 thin downslope from $>150 \mathrm{~m}$ thickness to a 40-m-thick sequence of shelf claystones (see supplementary data S2). This prograding post-Kettla Tuff Mb volcaniclastic unit remains equivocal. It either demonstrates that lower Thanetian volcanism in the FSB did not cease with the eruption of the 


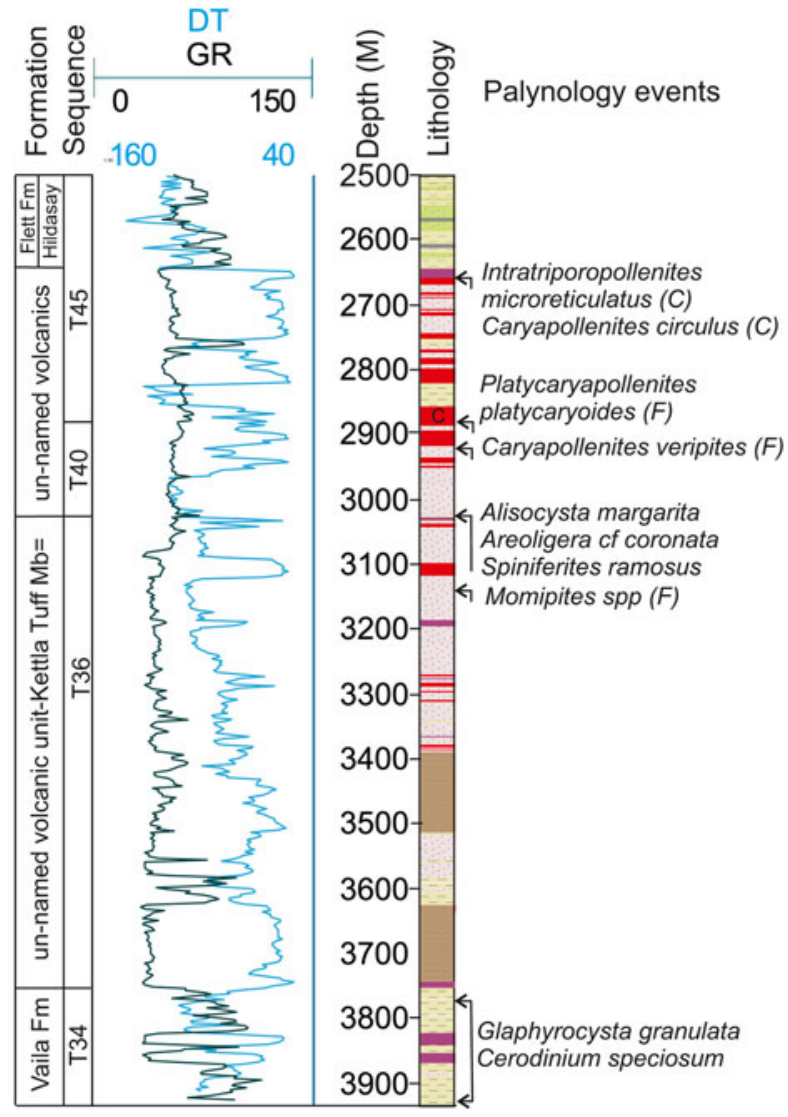

Figure 6 6004/8a-1 Anne Marie: because of drilling problems, samples from this well are dominated by cavings making presentation of the quantitative palynological data irrelevant. The qualitative data presented here help identify the presence of lava fields of both Sequence T36 and sequences T40-T45. Sequence T40 may extend further uphole, but is tied to the first downhole occurrence of frequent Platycaryapollenites platycaryoides and Caryapollenites veripites. Note that Sequence T34 is represented by Vaila Formation siliciclastic sedimentary rocks with minor intrusions.

Kettla Tuff Mb, or it marks erosion of the Kettla Tuff $\mathrm{Mb}$ on the updip shelf during upper Sequence T36 progradation.

\section{Syn-breakup volcanic activity}

Extensive, dominantly basaltic ash deposits across the NE Atlantic margin have been associated with the flooding of the NE Atlantic rift and the onset of ocean crust emplacement (Saunders et al. 1997; Jolley \& Widdowson 2005; Watson et al. 2017). Reaching a maximum abundance within the transgressive marine sediments of the Balder Formation (Fig. 2), Knox \& Morton (1988) attributed concentrations of pyroclastic ashes within the earliest Eocene of the North Sea Basin to their Phase 2 event. Within the FSB, Phase 2 pyroclastic activity has been recorded from within the oldest part of the Flett Formation, the overlying Balder Formation to within the Horda Formation (sequences T40-T60 of Ebdon et al. 1995; see Fig. 2) by Ritchie et al. (2011). The Phase 2 pyroclastic record of the North Sea extends east down the prevailing NW wind direction (Knox \& Morton 1988) into Denmark and southeastern England (e.g., Heilmann-Clausen 1985; Jolley 1996), indicating phreatomagmatic eruptions during the period $\sim 57-54.5 \mathrm{Ma}$. A comparable distribution pattern for the older Flett Formation (sequences T40 and T45) pyroclastic deposits within the Faroe-Shetland, Rockall and North Sea basins and in Denmark (e.g., Heilmann-Clausen 1985) indicates that phreatomagmatic activity associated with the nascent $\mathrm{NE}$ Atlantic Rift began as early as $56.5 \mathrm{Ma}$.

\subsection{Onset of syn-breakup volcanism}

Subsurface drilling within the FSB has encountered widespread extrusive volcanism, which is bracketed by, or interdigitated with, marine sediments of upper Thanetian to lower Ypresian age. Many of the wells in the region record penetrations of lava fields erupted during Sequence T40 (Ebdon et al. 1995; Fig. 2). These include multiple shield and fissure lava fields of the exposed Beinisvøro Formation of the FIBG (Passey \& Jolley 2009), localised, largely fissure fed lava fields on the Corona Ridge (Schofield \& Jolley 2013; Hardman et al. 2017) and the thick lava packages of the NE FSB encountered at the 217/151Z Lagavulin well (Millett et al. 2016; Fig. 13). The extensive lava fields in the W of the FSB initiated within Sequence T40 (Ebdon et al. 1995) and are broadly coeval, with the oldest evidence for pyroclastic Phase 2 (Knox \& Morton 1988; Jolley 2009; Passey \& Jolley 2009; Schofield \& Jolley 2013).

3.1.1. East Faroe High. The thickest subsurface succession of Sequence T40 lavas was drilled by two wells on the Brugdan prospect at the edge of the East Faroe High (Figs 1, 8, 11). The two wells are immediately adjacent to each other following technical difficulties with the first drilled, 6104/21-1. Penetrating the $2.5 \mathrm{~km}$ of FIBG volcanic rocks adjacent to the East Faroe High, well 6104/21-1 (Fig. 11) reached terminal depth (TD) at $4225 \mathrm{~m}$. Underlying the FIBG lava field were mid-shelf marine shales and sandstones. These are attributed to the Selandian to Thanetian uppermost Vaila and Lamba formations and have been extensively intruded by dolerite sills (Ellis \& Stoker 2014; Figs 8, 11). Samples from these shales yielded the dinocysts $A l$. margarita and Areoligera gippingensis, taxa characteristic of Thanetian shelf open-circulation marine sediments of sequences T35-T38 (Figs 2, 8, 11).

In these wells, the overlying FIBG volcanic succession is composed of hyaloclastite breccias and basaltic lavas with interbedded sedimentary rock units. In 6104/21-1, between $2200 \mathrm{~m}$ and $3050 \mathrm{~m}$ the volcanic succession contains occurrences of the dinocysts Apectodinium parvum, Apectodinium homomorphum, Apectodinium summissum, Deflandrea oebisfeldensis and frequent occurrences of the angiosperm pollen Caryapollenites veripites and Alnipollenites verus, indicating attribution to the upper part of Sequence T40 (Schofield \& Jolley 2013; Fig. 2). Closely similar terrestrially derived palynofloras have been recorded from the upper Forties Mb, Sele Formation of the North Sea (Schroder 1992; Kender et al. 2012), a deposit of equivalent age. Here the event has a first-order correlation with the recovery phase of the Paleocene-Eocene-Thermal-Maximum (PETM) Carbon-13 $\left(\delta_{13} C\right)$ excursion (Kender et al. 2012; Eldrett et al. 2015).

Within the Sequence T40 interval of well 6104/21-1 (Fig. 11), there is evidence for progradation of hyaloclastite deltas passing up into emergent lava fields in two major cycles. The emergent lava field stage of each cycle was locally submerged by a rise in relative sea level, marked by an influx of dinocysts and other algae during a maximum flooding event. Interaction between the changes in relative sea level and lava field progradation have been recorded in the FIBG (Passey \& Jolley 2009; Jolley et al. 2012; Wright et al. 2012). Their occurrence in the East Faroe High area indicates that overall subsidence caused the lava field to remain at near sea level throughout eruption.

Repeated cycles of eruption are also recorded in hyaloclastite delta and lava field prograding successions within Sequence T40 in well 217/15-1z (Millett et al. 2016; Fig. 13). The dominantly volcanic and volcaniclastic succession penetrated in the 217/ $15-1 \mathrm{z}$ well yielded limited palynofloras because of the proximal volcanic depositional system. However, the co-occurrence of common A. verus and Cupuliferoidaepollenites liblarensis above $2620 \mathrm{~m}$ indicates attribution to Sequence T40 (Fig. 2; McLean et al. 2017). 


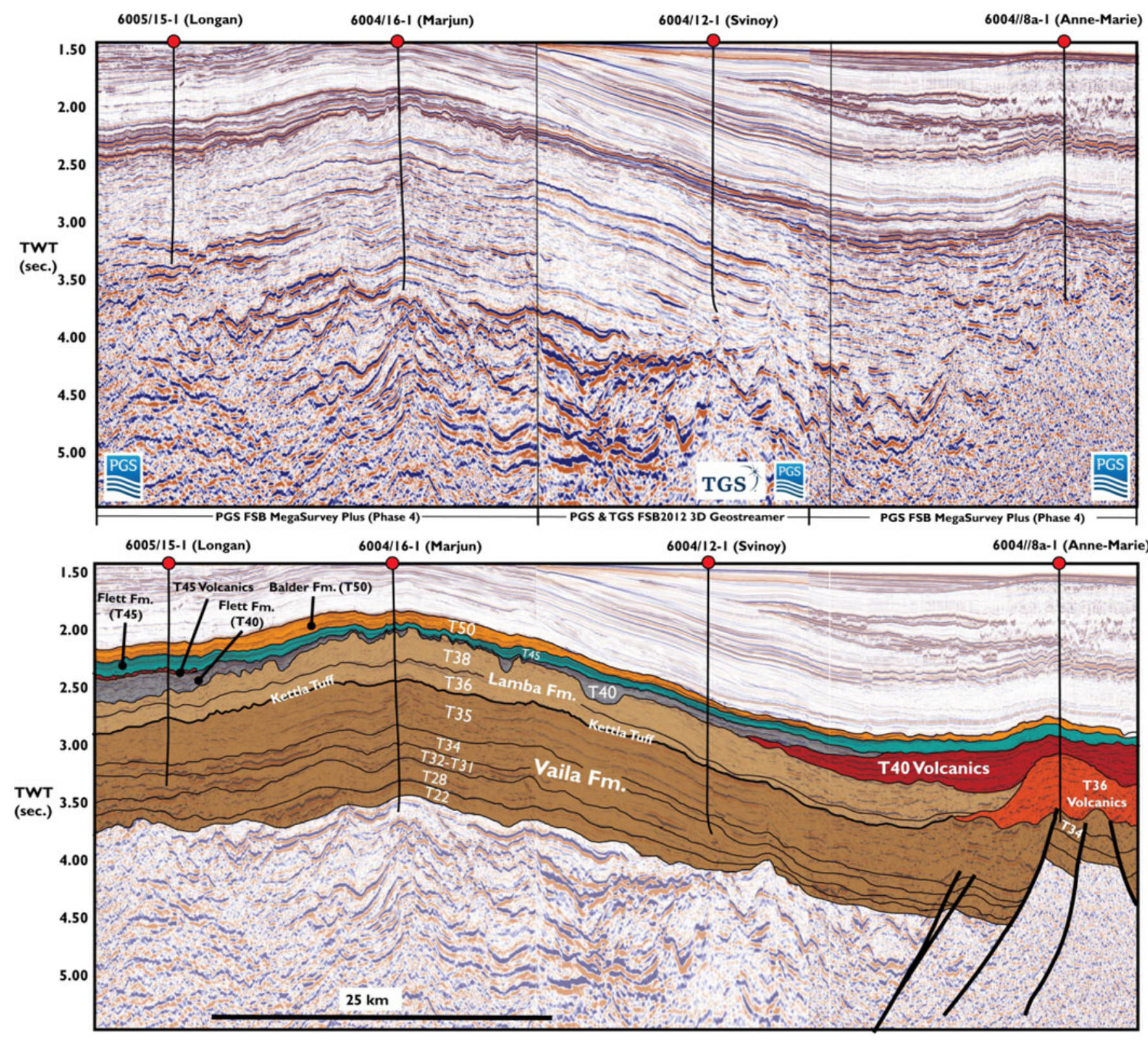

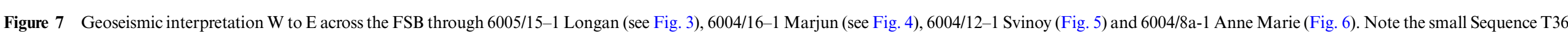

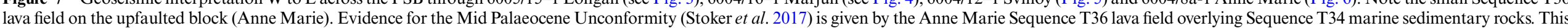

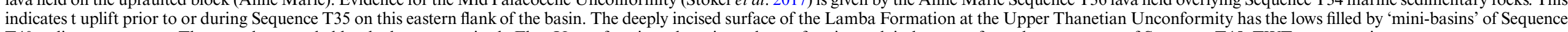
T40 sedimentary strata. These are later eroded by the lower magnitude Flett Unconformity, whose irregular surface is overlain by strata from the upper part of Sequence T45. TWT: two way time. 


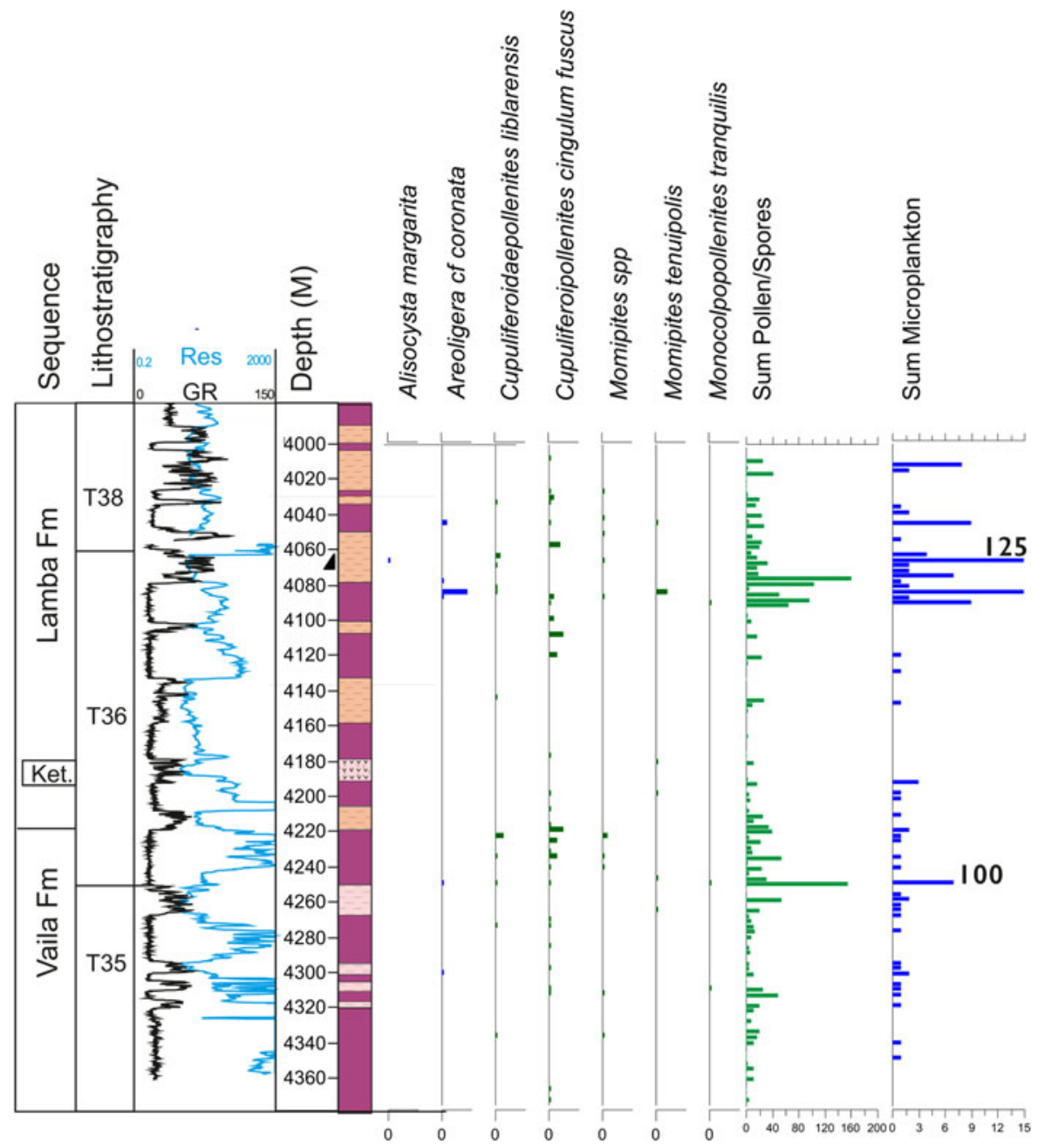

Figure 8 Brugdan 6104/21-2. Both the Lamba and Vaila formations are extensively intruded with sills. Palynomorphs recovered from intervals of these sills are cavings from the overlying sedimentary rocks and reflect the difficulties in drilling such variably resistant strata. Identified from its log signal and from examination of the ditch cuttings, the volcaniclastic Kettla Tuff Mb (Ket.) occurs near the base of the Lamba Fm (Sequence T36). Within the FSB, this lower Lamba Formation interval is marked by frequent to common Momipites and Cupuliferoipollenites species, the base of which is used to determine the oldest Sequence T36 sediments in this well. Stratigraphically significant species palynomorph data are displayed as square root values. In samples with highly variable individual counts, presented data as percentages would be misleading. Sum pollen/spores and sum microplankton are plotted as standardised counts and demonstrate variable recovery in this succession.

3.1.2. Corona Ridge. The thick FIBG flood basalt lava fields attributed to Sequence T40 extend eastwards towards the Corona Ridge. There are few well penetrations in this area, but 6104/25-1 (Sula Stelkur; Fig. 14) W of the Corona Ridge recorded hyaloclastite breccias overlain by volcaniclastic sediments above TD. These strata contain occurrences of Apectodinium species, abundant Platycaryapollenites platycaryoides and common $C$. veripites, indicating attribution to the earliest Ypresian interval of Sequence T40 (Fig. 2). The lack of deeper well penetrations in this area and the difficulties of seismic interpretation in thick basalt successions leave a question over the facies of the undrilled thick volcanic succession below TD. However, geoseismic interpretation (Fig. 7) and evidence from the thickness of Sequence T40 volcanic successions on the adjacent Corona Ridge (Schofield \& Jolley 2013) indicate that the Sequence T40 volcaniclastic rocks in 6104/25-1 were probably the southeastern prograding volcaniclastic margin of the FIBG.

On the Corona Ridge, multiple well penetrations around the Rosebank, Cambo and Tobermory fields (Fig. 1) have yielded stratigraphical and depositional facies data that have been integrated with seismic interpretation (Schofield \& Jolley 2013; Hardman et al. 2017, 2018; Watson et al. 2017). Lava flow fields and associated volcaniclastic sediments of Sequence T40 (Schofield \& Jolley 2013) are interbedded with siliciclastic sedimentary rocks deposited by the Flett Delta system, termed the Colsay $\mathrm{Mb}$ (Hardman et al. 2017). These rocks were deposited in fluvial floodplain, estuarine and shelf marine facies yielding diverse pollen/spore and microplankton palynofloras (Fig. 15). The oldest Sequence T40 rocks drilled in Rosebank Field well 213/27-2, the volcaniclastic sedimentary rocks of Colsay 4 (HellandHansen 2009; Poppitt et al. 2018), rest unconformably on argillaceous marine sedimentary rocks of the Thanetian Lamba Formation. These are characterised by abundant occurrences of the dinocyst Alisocysta margarita (Figs 2, 15). The abundant occurrences of the PETM proxy (Crouch et al. 2003) dinocyst Apectodinium augustum within Colsay 3 and in interbeds within the Rosebank Lower Volcanics (Schofield \& Jolley 2013; Fig. 14), confirm the stratigraphical relationship of these strata to the PETM carbon isotope excursion (CIE). The subsequent post-CIE recovery is recorded in Sequence T40, upper Colsay 3 sedimentary rocks, but is truncated by the Flett regional unconformity (e.g., Shaw Champion et al. 2008). This interval from uppermost Colsay 3 to the Sequence T40-Sequence T45 boundary within Colsay 1 is characterised by common $C$. veripites and $P$. platycaryoides pollen. The upper part of this interval also contains common occurrences of Azolla massulae and Sparganiaceaepollenites magnoides, both derived from aquatic/ aquatic marginal plant taxa, reflecting high moisture availability 


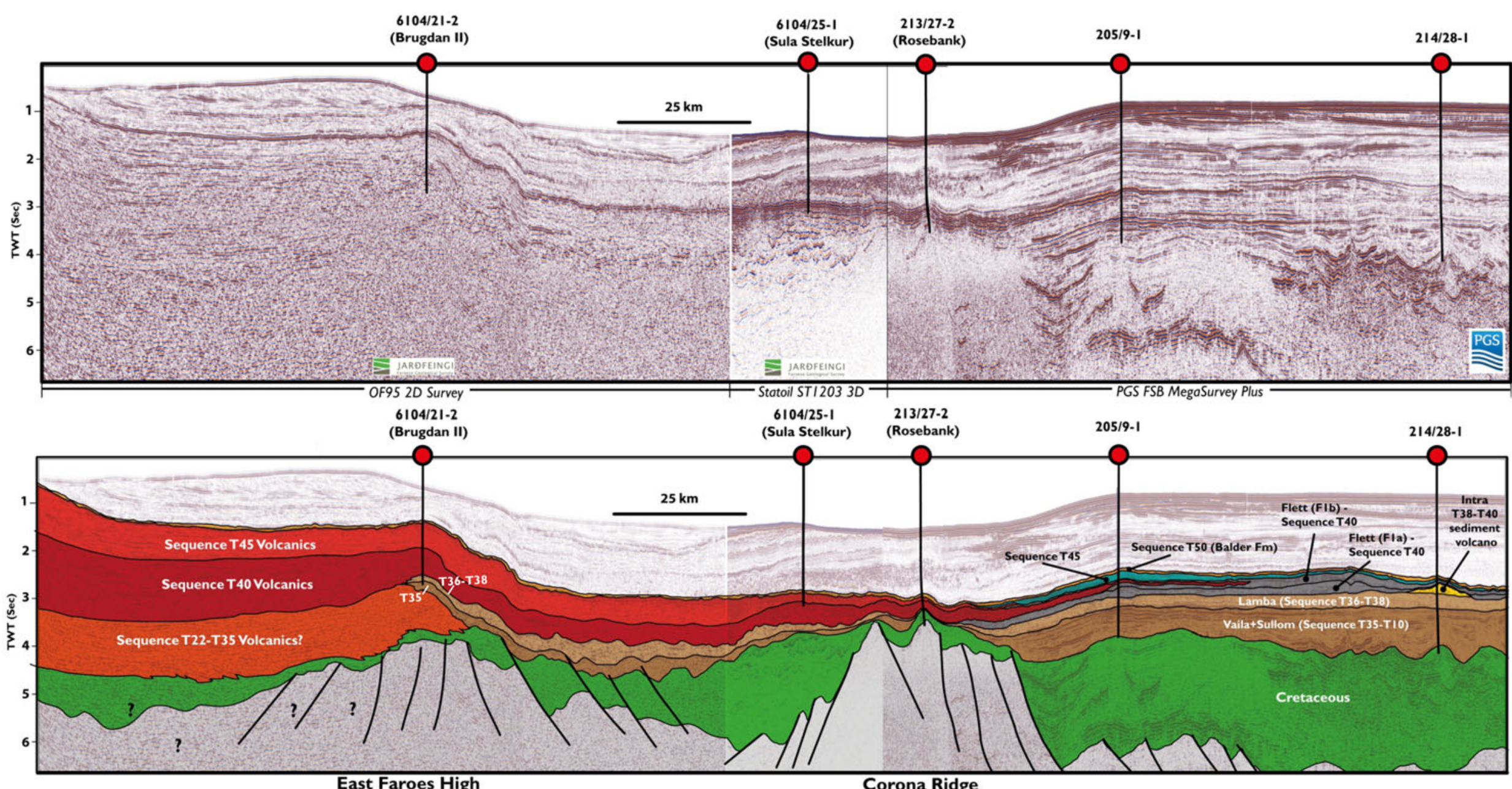

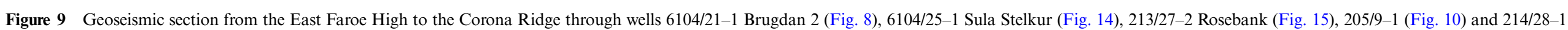

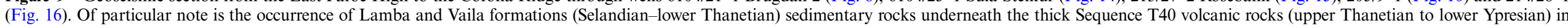

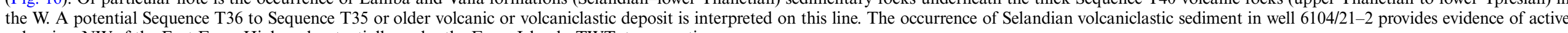
volcanism NW of the East Faroe High and potentially under the Faroe Islands. TWT: two way time. 


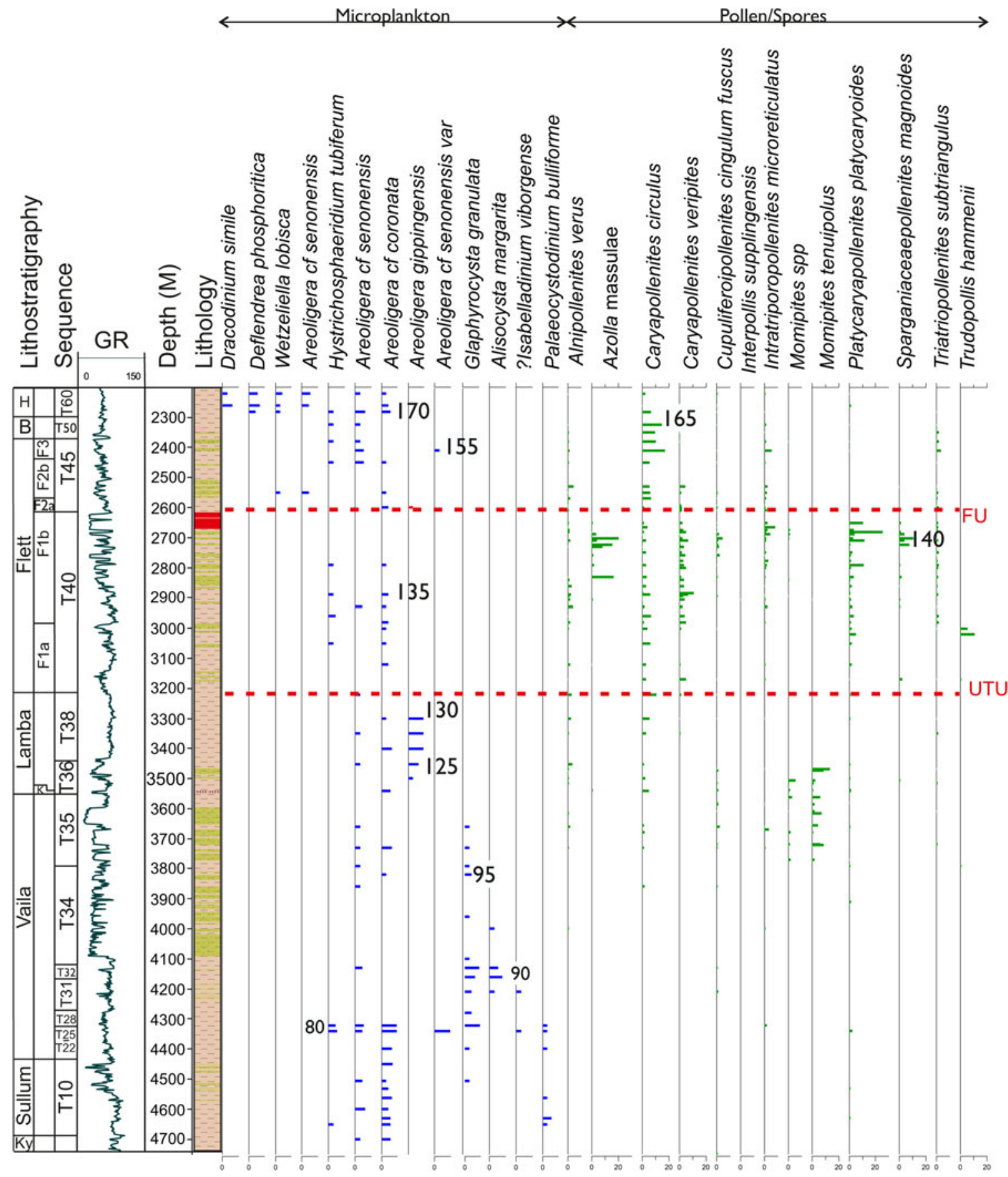

Figure 10 Well 205/9-1. This well contains an extensive sequence from the K/Pg boundary to the Early Eocene. It penetrated two notable volcanic intervals, the Kettla Tuff Mb in Sequence T36 and a small lava flow field in the upper part of Sequence T40. The occurrence of common Momipites tenuipolus within Sequence T36 and upper Sequence T35 is widespread in the FSB and is recorded in equivalent Thanet Sands Formation strata in southeastern England (Jolley 1998) sedimentary rocks that contain disseminated degraded volcanic ash. All palynomorph data displayed as square roots because of variable sample counts and to limit the physical width of the plot. Only stratigraphically significant taxa are displayed.

during deposition of upper Flett Formation Unit F1b. This assemblage has been recorded within the post-PETM recovery stage and is correlative with the uppermost units of the Forties Mb, North Sea Basin (e.g., Kender et al. 2012).

Regionally, the unconformity between the Lamba Formation marine shales and the overlying volcaniclastic and siliciclastic sediments of the Flett Formation is marked by a pronounced lithological and palynofacies change. In the offshore record, structured organic ( pollen/spores and algae), vitrinite and abundant amorphous organic kerogen characterise the lower Flett Formation. These assemblages contrast with those of the Lamba Formation, which has low diversity/high dominance pollen and spore floras, rich dinocyst-dominated microplankton floras and inertinite-rich kerogen. This abrupt change is a consequence of uplift and erosion across the basin at the Sequence T38/Sequence T40 boundary. It is coincidental with, or rapidly followed by, initiation of flood basalt eruption (Fig. 7). The correlative unconformity, also marked by a basinward shift in facies, is seen on the western margin of the North Atlantic rift in E Greenland (Jolley \& Whitham 2004; Parsons et al. 2017).

3.1.3. Flett Sub-basin. Within this dominantly marine sedimentary basin, the sea floor vent system drilled in well 214/28-1 is of particular interest (Fig. 16). Originating as from a deeper intrusive sill complex, the vent formed on the sea floor at the unconformity between Sequence T38 and Sequence T40 (Schofield et al. 2015). Vent formation was immediately predated by the intrusion of a sill complex. The sill complex induced a forced 


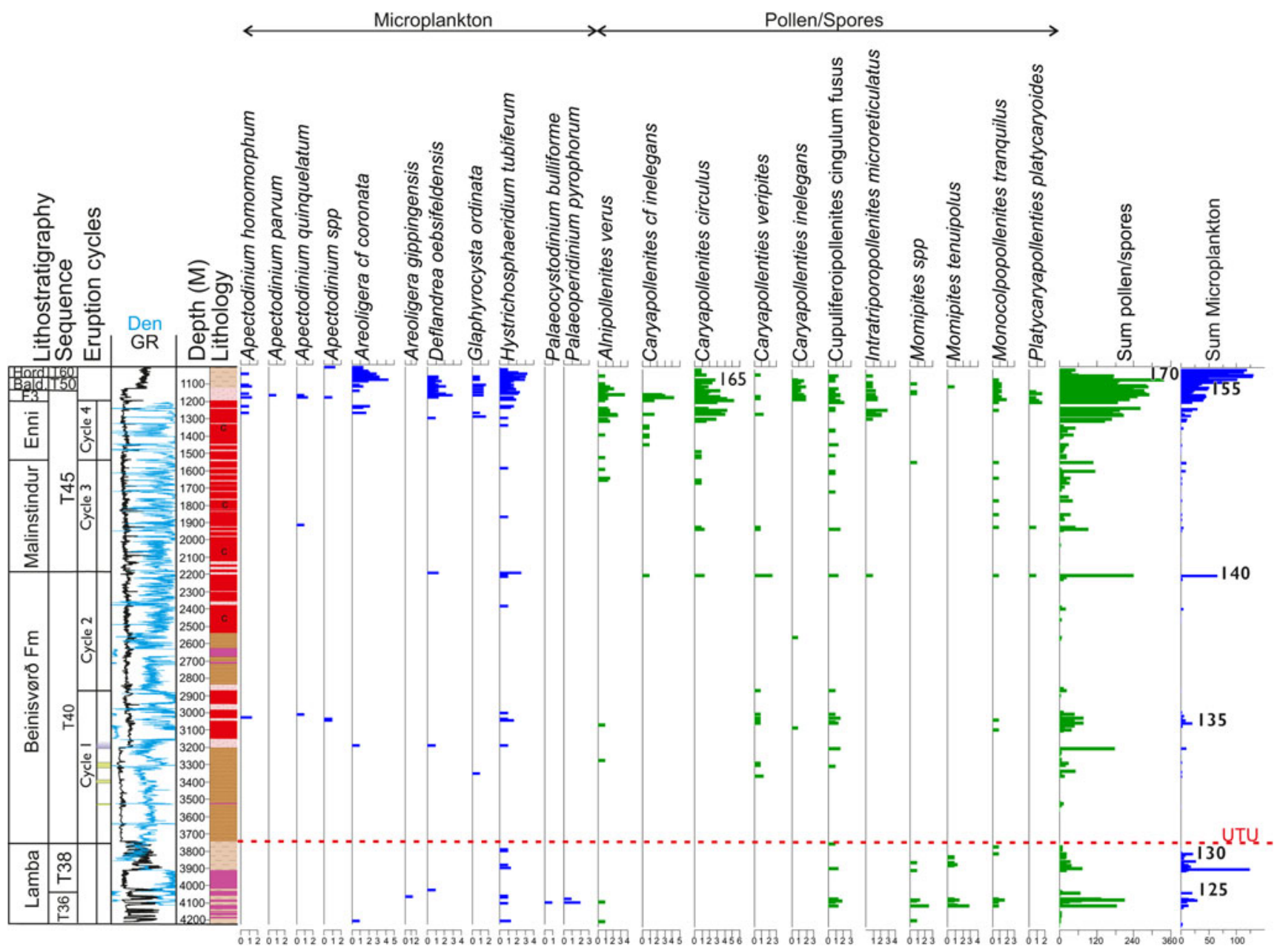

Figure 11 Brugdan 6104/21-1. The sub FIBG Lamba Formation marine sediments are heavily intruded. The occurrence of diverse dinocyst palynofloras, including Areoligera gippingensis and Hystrichosphaeridium tubiferum, indicate deposition in an open marine mid-shelf environment. Influxes of Momipites species are characteristic of lower Sequence T36. Overlying the Lamba Formation are two hyaloclastite-flow field cycles, the upper part of Cycle 1 containing specimens of Apectodinium species (focussed at MFS 135) and frequent Alnipollenites verus and Caryapollenites veripites. This palynoflora indicates that the lava field penetrated in this well is within the upper part of Sequence T40. Because of the record of this flora derived from Cycle 1 interbeds, it is possible that the hyaloclastite interval of lower Cycle 1, with a low organic matter preservation potential, is also attributable to upper Sequence T40, forming part of the same depositional cycle. Relative sea level change within the Cycle 1 hyaloclastites is highlighted by influxes of pollen/spores and some algae (green and blue bars in the Eruption cycles column, respectively). These influxes are linked to eruption slow down and suggest a water depth of $>100 \mathrm{~m}$. The upper limit of the Sequence T40, Beinisvørð Formation equivalent lava succession is marked by the first downhole occurrence of common C. veripites, co-occurring with MFS140, which introduced common $H$. tubiferum and Deflandrea oebisfeldensis. All species palynomorph data displayed as square roots because of variable total counts; only stratigraphically significant taxa are displayed. Sum pollen/spores and sum microplankton are standardised raw totals to illustrate variable recovery.

fold in the overlying strata, demonstrated by the asymmetric onlap of the vent cone onto the anticline. The vent cone is composed of redeposited Lamba Formation sediment (Fig. 16), including a reworked dinocyst flora containing Areoligera gippingensis and Alisocysta margarita. Overlying the vent deposits are marine turbidites of the Flett Formation (Grove 2013; Schofield et al. 2015), the lowermost beds of which contain common occurrences of Areoligera cf. coronata, Deflandrea oebisfeldensis, Alnipollenites verus and Caryapollenites circulus. These taxa are characteristic of the oldest, pre-PETM sediments of Sequence T40 - the influx of common Apectodinium augustum at $2934.64 \mathrm{~m}$ provides a confirmation of the assigned age and a proxy for the PETM hyperthermal (Crouch et al. 2003; Kender et al. 2012; Fig. 16). This species occurs in association with Apectodinium parvum, Apectodinium paniculatum and Apectodinium homomorphum, taxa which occur in both deeper and transitional marine facies of Sequence T40 following the PETM inception. Common occurrences of Caryapollenites veripites from $2529.84 \mathrm{~m}$ to $2807.21 \mathrm{~m}$ are characteristic of the recovery phase of the PETM in both the FSB and North Sea Basin. The association of these taxa with common Platycaryapollenites platycaryoides and A. verus is typical of earliest Ypresian palynofloras (Schroder 1992; Beerling \& Jolley 1998; Kender et al. 2012) and help to define the upper boundary of Sequence T40. The vent in well 214/28-1 occurs at the base of Flett Formation unit F1a (Fig. 2), some $60 \mathrm{~m}$ beneath the proxy for the PETM inception. Intrusion of this part of the FSSC was, therefore, not coincidental with the onset of the PETM CIE.

In volcanic successions (e.g., 217/15-1z; Fig. 13), the interval between the base of the Flett Formation/Sequence T40 and the first stratigraphical occurrence of the dinocyst proxy for the PETM is difficult to identify. In several wells, hyaloclastite deltas which contain transitional facies algae with long stratigraphical ranges rest directly on older Thanetian sedimentary rocks, or the contact is undrilled. This interval is also absent on basin highs, both in sedimentary and volcanic successions (Fig. 15). However, on the western flank of a tilted fault block, well 205/9-1 (Jolley 2009; Schofield \& Jolley 2013; Fig. 9) preserves this interval in clastic sedimentary rock facies. The Thanetian to Ypresian transition is marked by sandstones and shales deposited in a shallowing upwards succession capped by two basalt lava flows, separated by a sedimentary interbed. The oldest, Thanetian 


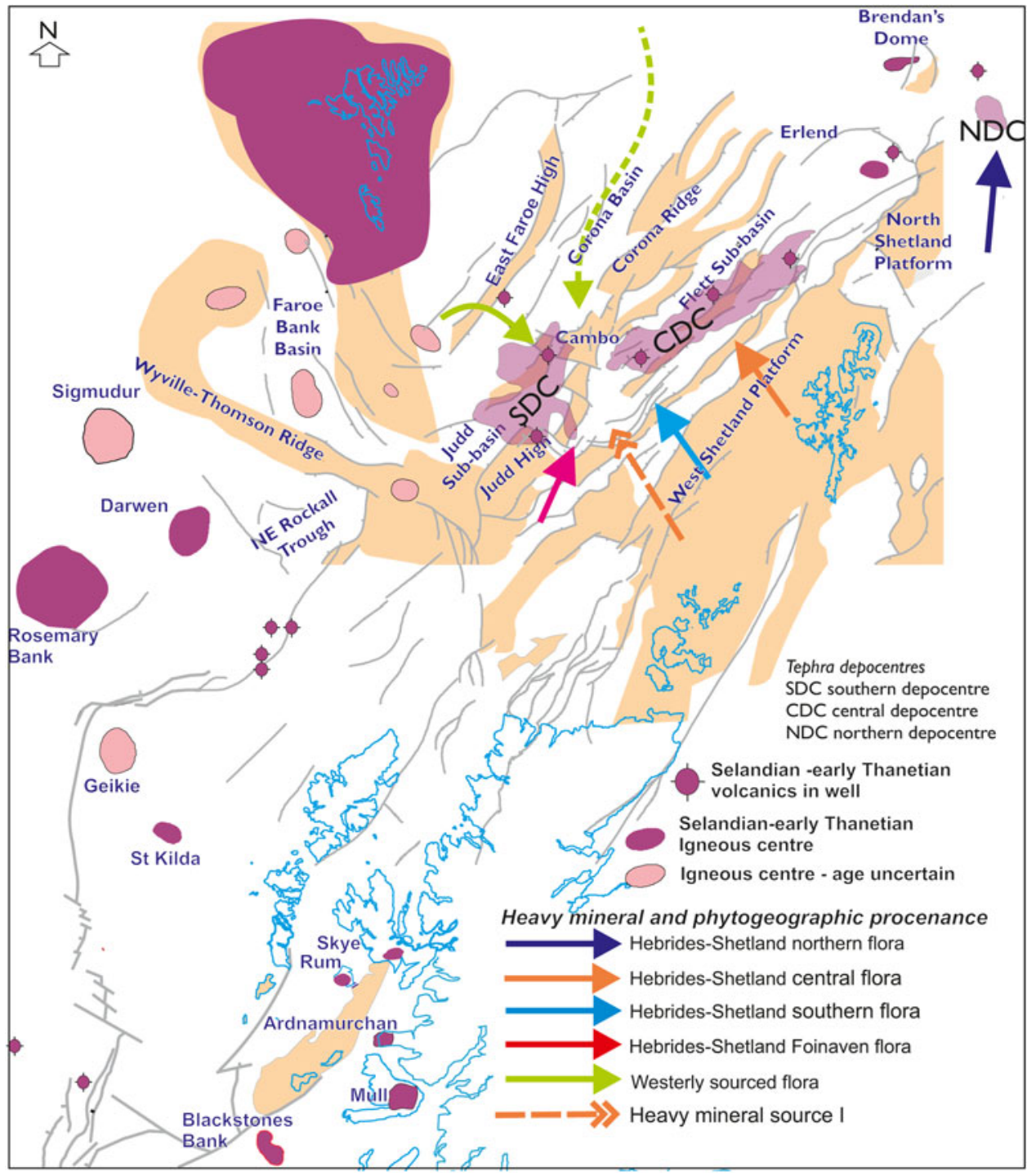

Figure 12 Map showing the location of pre-breakup volcanism in the Faroe-Shetland and Rockall basins. Only wells penetrating volcanics are shown, alongside seamounts of known age and correlative onshore exposures in the BPIP. The extent of the pre-breakup volcanic succession under the Faroe Islands is conjectural. The tephra depocentres are those of Watson et al. (2017) and the heavy mineral and phytogeographic provenance pathways are after Jolley \& Morton (2007). Note that the tephra depocentres are basins with input from differing catchments.

part of this succession (Flett unit F1a in Fig. 9) is characterised by marine palynofloras with common $A$. cf. coronata. Above this, palynofloras were deposited in a shallow marine environment, which introduced abundant higher plant material. Because of the transitional fluvial to shallow marine facies, dinocysts belonging to the genus Apectodinium do not occur commonly in this well. However, common specimens of $C$. veripites, . platycaryoides and, from $2831 \mathrm{~m}$ to $2722 \mathrm{~m}$, common Azolla massulae associated with Sparganiaceaepollenites magnoides are characteristic of the upper part of Flett Formation Unit F1b and the post-PETM recovery phase. A. massulae and $S$. magnoides are aquatic/aquatic marginal taxa, which occur in the Sequence T40, Colsay 1 interval interbeds on the Corona Ridge (e.g., Rosebank field well 213/27-2; Fig. 15).

The position of the PETM hyperthermal event within the Flett Formation was constrained using bulk paly $\delta^{13} \mathrm{C}$ for well 6005/15-1 (Fig. 3; supplementary data S3). The CIE excursion is recorded in the uppermost part of Sequence T40 preserved in this well. However, the characteristic CIE profile is truncated by the Flett unconformity (Shaw Champion et al. 2008; Hartley et al. 2011) at the Sequence T40-Sequence T45 boundary. Influxes of $A$. verus, $C$. veripites and P. platycaryoides define the upper limit of Sequence T40 in this well.

\subsection{Later syn-breakup volcanism}

Later syn-breakup volcanism attributed to Sequence T45 included lava flow fields which were geographically limited in comparison to those of Sequence T40. These flow fields are thickest towards the Faroe Islands (Malinstindur and Enni formations; Passey \& Jolley 2009), and were drilled in the Brugdan prospect on the margin of the East Faroe High. In well 6104/21-1 on the East Faroe High (Figs 1, 11), a succession dominated by compound flows passes up-section into mixed compound and tabular sheet flows, similar to the onshore upper Malinstindur and Enni formations (Passey \& Jolley 2009; Millett et al. 2017). The interbedded sedimentary rocks in this sequence yielded terrestrial palynomorphs, which become more abundant up-section. These increasingly diverse floras also exhibit later seral successional status, indicating decreasing vegetation community disturbance in response to the slowing eruption rate (e.g., Jolley et al. 2012).

On the western flank of the Corona Ridge, Sequence T40 volcaniclastic rocks in well 6104/25-1 (Fig. 14) are overlain by ca. $300 \mathrm{~m}$ of flood basalt with subordinate volcaniclastic sedimentary rock units attributed to Sequence T45. Although the current seismic interpretations (Fig. 9) do not allow identification of the source of these flows, local fissures on the Corona 


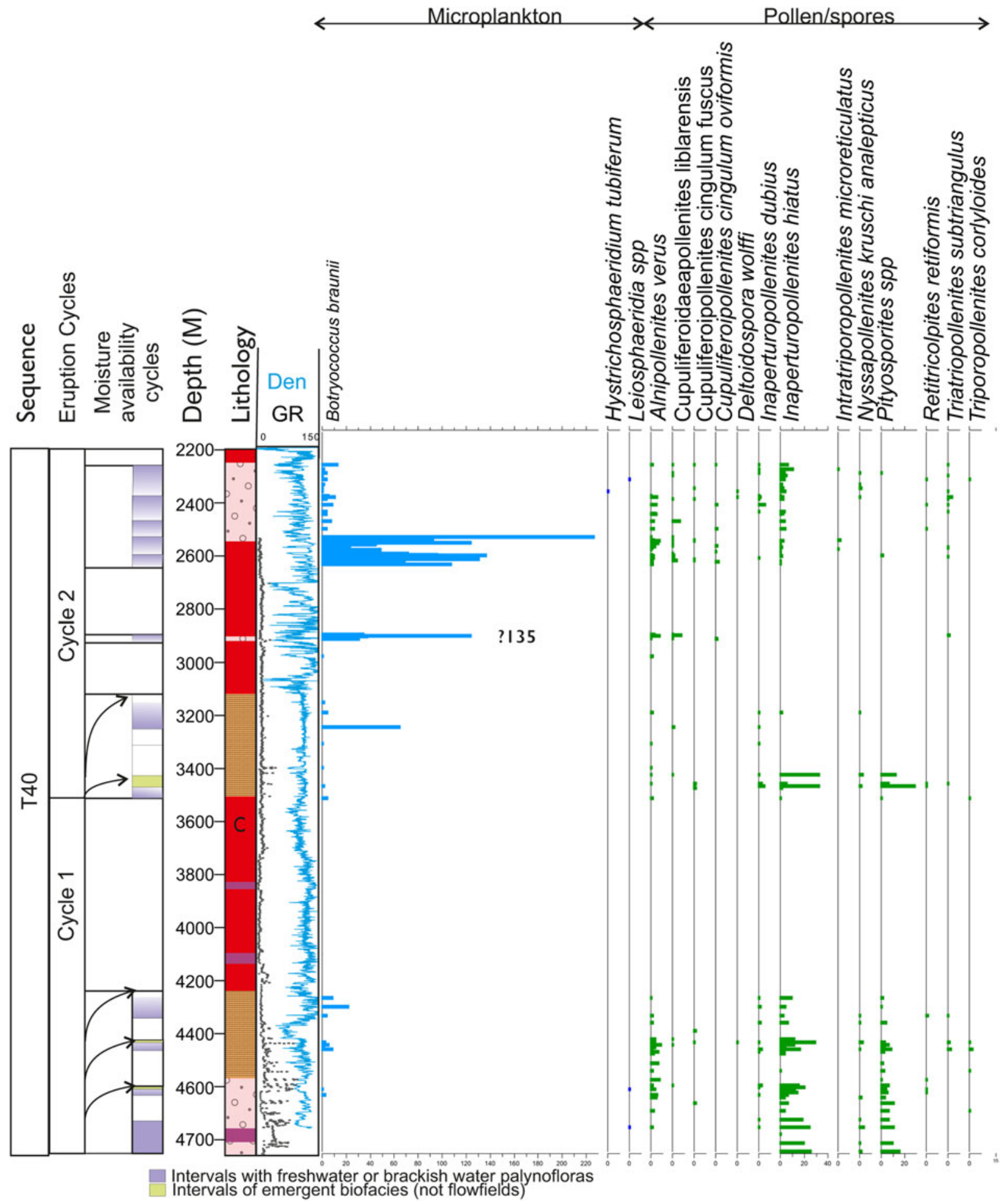

Figure 13 219/21-1 Lagavulin well. The well log is derived from Millett et al. (2016), showing the magmatic cycling recorded by those authors. In the hyaloclastite succession at the base of the well, evidence from influxes of terrestrial palynomorphs and low salinity/freshwater algae define a period of slower eruption. These suggest water depths of $\sim 100 \mathrm{~m}$, the hyaloclastite delta potentially becoming emergent updip of the wellsite. Because this well is close to the source of high-volume eruption, age determination is difficult. However, the influx of common Alnipollenites verus and occurrences of Triatriopollenites subtriangulus in the upper part of Cycle 2 suggest an age no older than Sequence T40. All pollen and spore data are displayed as square roots, the chlorophycean algae Botryococcus braunii is displayed as raw data to emphasise the high-volume intra-lava occurrences. Only stratigraphically significant taxa are displayed.

Ridge are recognised as being the source of Sequence T45 lava fields (Schofield \& Jolley 2013). These locally erupted compound flow fields were recorded in the Cambo and Rosebank fields area (Fig. 1; Schofield \& Jolley 2013), thinning towards a zone of inter-digitation with estuarine and marine sedimentary rocks to the N. Additionally, these locally sourced lava fields are also recorded to the W and $\mathrm{S}$ of the Corona Ridge in well 6005/151 (Fig. 3). Here, a succession of upper Flett Formation inner shelf marine to fluvial sedimentary strata includes two thin basalt lava flows (Jolley 2009; Schofield \& Jolley 2013). This succession is overlain by marine sediments deposited during the uppermost Flett Formation transgression. This transgression is recorded basin-wide - for example, overlying the Enni Formation flow field in well 6104/21-1 (Fig. 11). Here, shelf marine volcaniclastic rocks are characterised by a dinocyst flora including common Deflandrea oebisfeldensis, Hystrichosphaeridium tubiferum and 


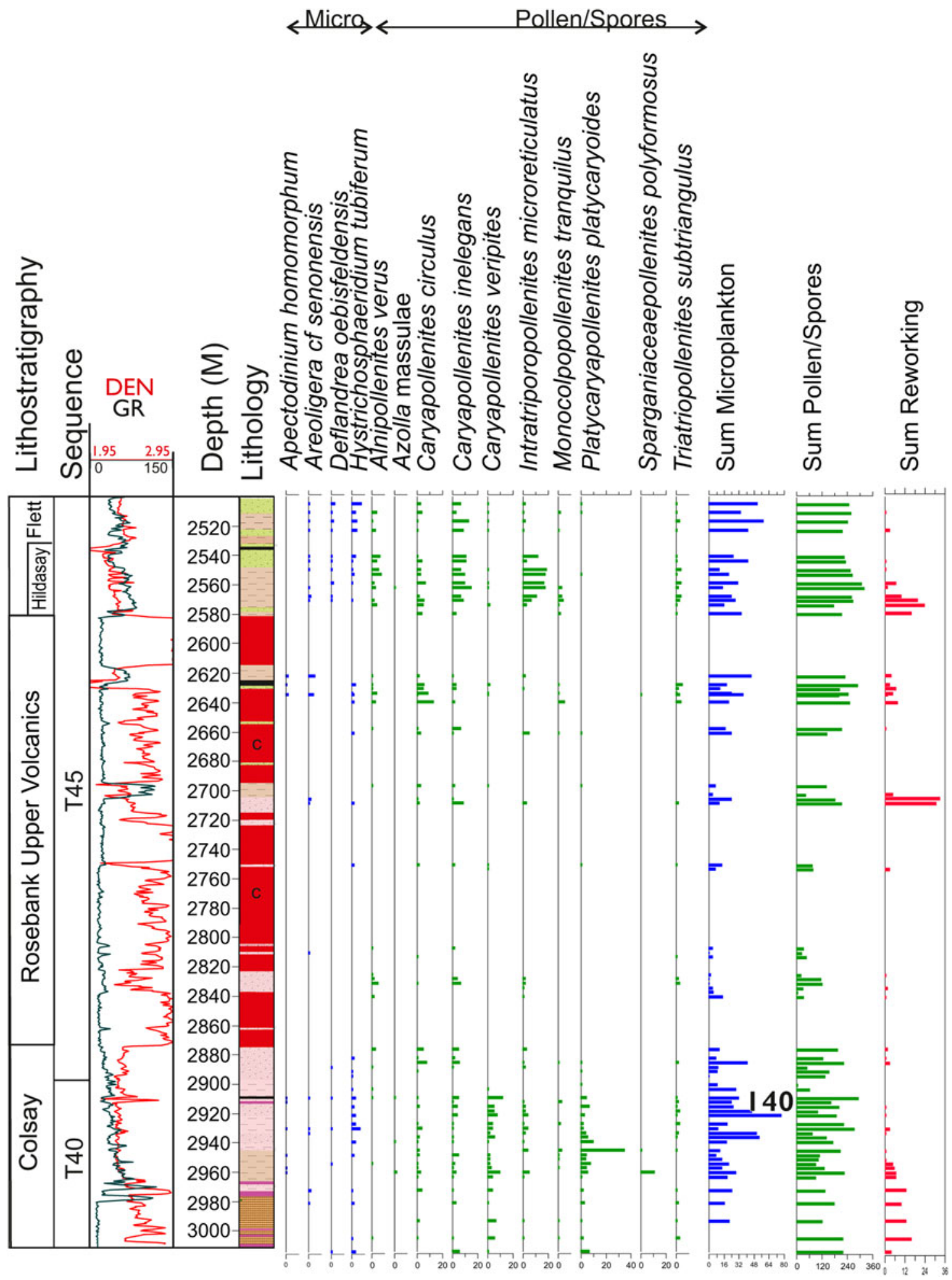

Figure 14 6104/25-1 Sula Stelkur. The upper limit of Sequence T40 is defined by the first downhole occurrence of common Caryapollenites veripites, coinciding with an influx of the dinocyst Hystrichosphaeridium tubiferum. The overlying lava succession contains interbeds with occurrences of Caryapollenites circulus, although all interbeds yield dinocysts indicating marine influence through eruption of the lava field. Reworking of dominantly Jurassic spores and pollen reflect interaction of the Flett Delta system with the lava field. All species palynomorph data displayed as square roots because of variable sample totals; only stratigraphically significant taxa are displayed. Sum pollen/spores, sum microplankton and sum reworking are plotted as raw data to illustrate intervals of variable recovery.

Apectodinium species (but excluding Apectodinium augustum). Comparable microplankton records have been made from uppermost Flett Formation siliciclastic sedimentary rocks on the Corona Ridge (Figs 14-16), indicating that volcanism ceased on the Corona Ridge prior to that on the East Faroe High.

Although Sequence T45 flows are overlain by siliciclastic fluvial to shelf marine Hildasay $\mathrm{Mb}$ strata on the Corona Ridge, intra-Sequence T45 marine incursions are also recorded here (e.g., 6104/25-1 and 213/27-2; Figs 14, 15). Lava-bounded sedimentary rock successions of both marine and fluvial origin contain reworked, mainly Lower-Middle Jurassic palynomorphs. These reworked palynomorphs were probably eroded from structural highs or other Jurassic sediment sources and transported by the Flett Delta system. This delta system interdigitated with the Corona Ridge lava fields (Hardman et al. 2017), competing with them for depositional accommodation space. 


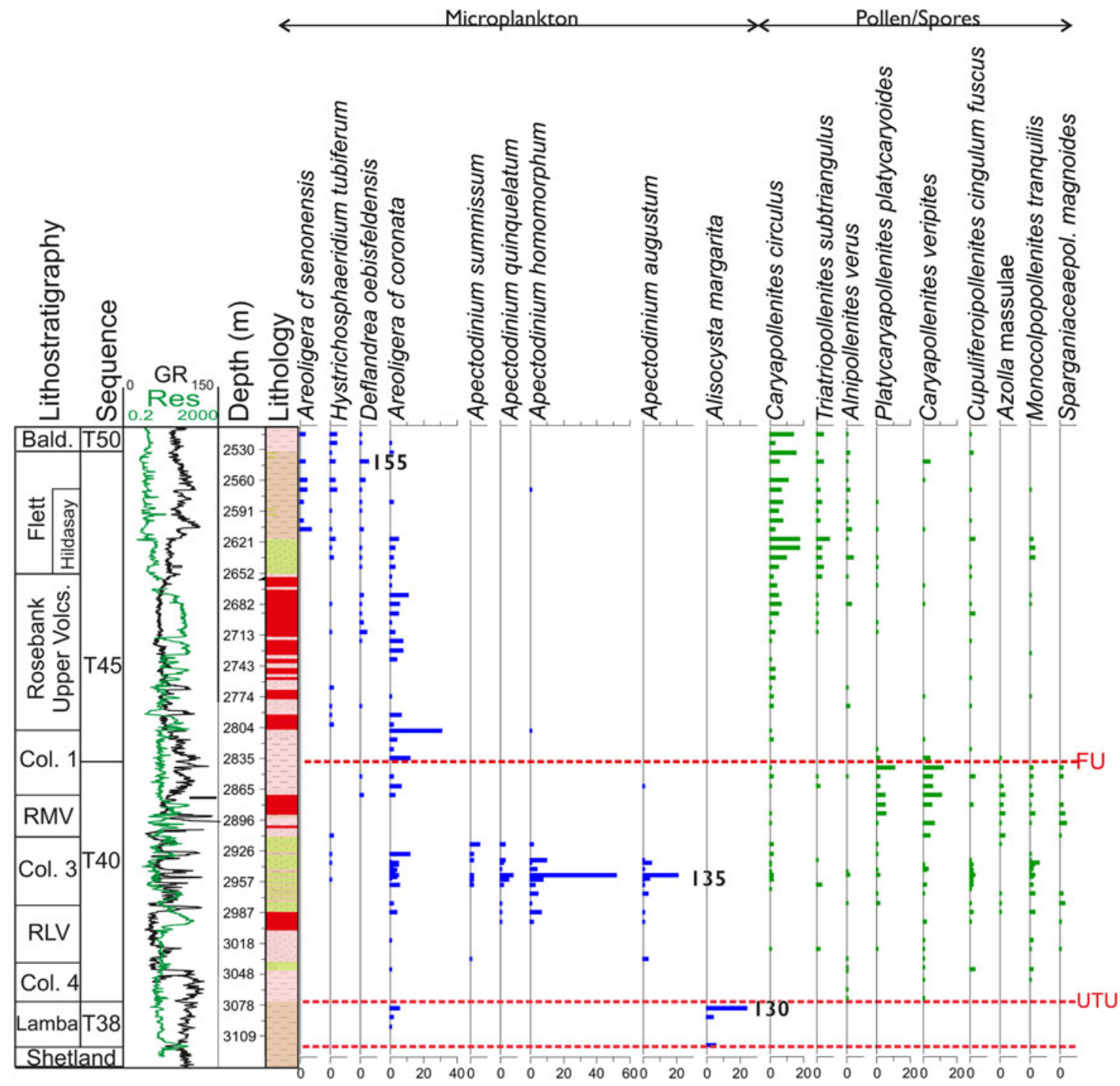

Figure 15 Well 213/27-2. Underlying the Rosebank Lower Volcanic (RLV) and Colsay 4 (Col. 4) volcaniclastic sedimentary succession are shallow-shelf marine shales of the Lamba Formation resting on the Cretaceous Shetland Group. An influx of common to abundant Alisocysta margarita indicates an age equivalent to Sequence T38 or older. An influx of Apectodinium species including common Apectodinium augustum in Colsay 3 (Col. 3) indicates MFS135, equivalent to the base of the PETM excursion event. The overlying Rosebank Middle Volcanics (RMV) and lower part of Colsay 1 (Col. 1) are dominated by pollen and shoreface dinocysts (Areoligera cf. coronata). Common occurrences of Caryapollenites veripites and Platycaryapollenites platycaryoides define the top of Sequence T40. Note that this falls within the Colsay 1 unit, a significant intra Colsay 1 unconformity is supported by the absence of MFS140 reflecting erosion/non-deposition at the Flett Unconformity. All species palynomorph data displayed as percentages; only stratigraphically significant taxa are displayed.

The resumption of marine sedimentation across the FSB after the cessation of eruptions was promoted by a lack of basin structuration. This is attributable to the topography-annealing influence of the recently erupted lava fields forming extensive basalt plains, in combination with continued reduction of thermal support within the region (Hardman et al. 2017). Lava field eruption in the FSB ceased in the earliest Eocene, but the basin continued to receive extensive ashfall during deposition of the Balder Formation. This reflects the shift of eruption activity towards the developing North Atlantic Rift, aligned on a NE-SW lineament away from the eastern peripheral zone (Fig. 17). This culminated in the flooding of the rift zone and the phreatomagmatic eruptions that sourced the geographically extensive ash deposits of the Balder Formation and correlative units.

\section{Volcanic successions in the Rockall Basin}

The Rockall Basin has fewer well penetrations and a lower density of seismic data coverage than the FSB. Recent re-appraisal of hydrocarbon prospectivity in the Rockall Basin to the $\mathrm{S}$ of the FSB
(Schofield et al. 2018; Broadley et al. 2020) has identified basin flank lava fields within both Sequence T40 and Sequence T36 along the eastern Rockall margin (Fig. 1). In this basin, the low density and quality of much of the subsurface samples or data has prevented recognition of any tephra deposits older than Thanetian.

Pre-breakup lower Thanetian (Sequence T36) lava fields identified by well penetrations in the Rockall Basin, to date, are small in overall spatial extent and are associated with shelf margin faulting (Fig. 1). These lava fields initiated as hyaloclastite deltas prograding westwards into the Rockall Trough. Successions of this character are recorded in wells $132 / 6-1,132 / 15-1,154 / 1-1$, 154/1-2, 153/5-1 and 164/28-1A (Figs 1, 11; and see Schofield et al. 2018). For example, well 164/28-1A penetrated a $\sim 300$-m-thick hyaloclastite sequence (Figs 18, 19) overlain by $\sim 100 \mathrm{~m}$ of a dominantly compound flow lava field. Overlain by Thanetian marine sedimentary rocks, this older lava field is, in turn, unconformably overlain by the prograding volcaniclastic and volcanic rocks of a syn-breakup, Sequence T40 lava field. Syn-breakup lava fields are extensive on the eastern Rockall Basin margin, but have fewer well penetrations (Fig. 17). 


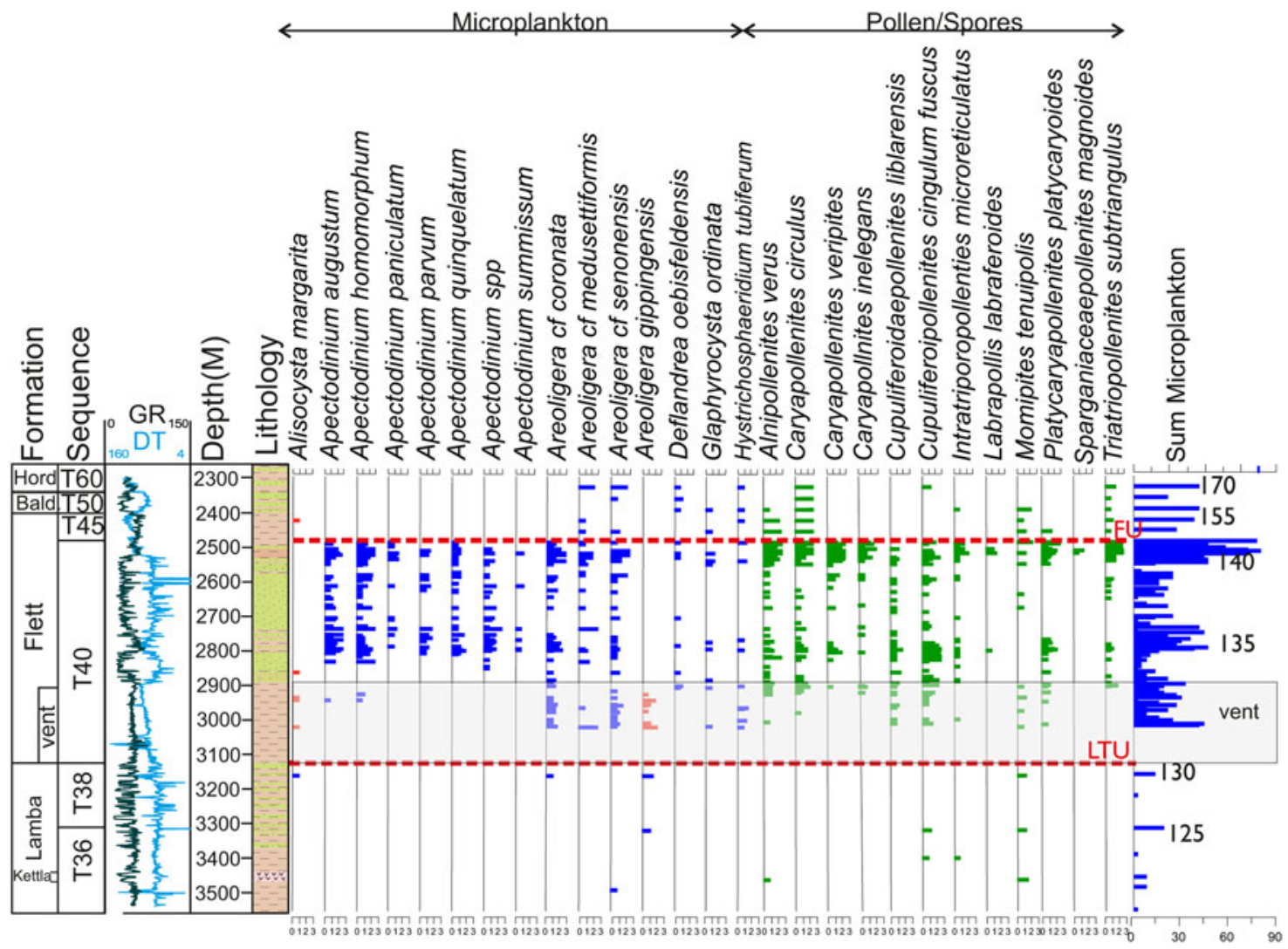

Figure 16 Well 214/28-1. This well penetrated a significant hydrothermal vent. Samples from beneath the hydrothermal vent system contain degraded palynofloras and thermally mature amorphous organic matter as a result of alteration by hydrothermal fluid flow. The Kettla Tuff Mb is defined from its wireline log signature. The hydrothermal vent was developed on the Upper Thanetian Unconformity, redepositing Lamba and Vaila formation sedimentary rocks, which have a uniform gamma-ray log signature. Overlying the vent ejecta are a succession of restricted circulation turbiditic marine shales and sandstones of Sequence T40. The interval between oldest common Apectodinium species, including A. augustum (MFS135) and the base of the turbidite succession is characterised by common Alnipollenites verus and Cupuliferoipollenites cingulum subsp., occurring with Areoligera cf. coronata, an assemblage typical of Flett Formation unit F1a. Flett Formation unit F1b is relatively thick in this well and includes an influx of common/abundant Caryapollenites veripites in the uppermost interval. This event if characteristic of the post-PETM excursion recovery stage in the North Sea Basin (e.g., Kender et al. 2012). Although Sequence T40 appears to be complete, the overlying Sequence T45 is strongly attenuated with no evidence for Flett Formation unit F2a being recorded. All species palynomorph data displayed as square roots because of variable sample totals; only stratigraphically significant taxa are displayed. Sum microplankton are plotted as raw data to illustrate intervals of variable recovery.

Wells 164/7-1 (Archer et al. 2005) and 164/25-2 to the NE (Figs $18,19)$ both drilled this succession. The most stratigraphically extensive, well 164/25-2 drilled a thick hyaloclastite delta succession, which had prograded from the $\mathrm{E}$ (Schofield et al. 2018) and overlying basaltic lavas in a succession comparable to those in the FSB. Further, Sequence T40 volcanic delta facies were drilled by well $154 / 3-1$, which penetrated approximately $500 \mathrm{~m}$ of hyaloclastites (Schofield et al. 2018) overlain by approximately $400 \mathrm{~m}$ of dominantly compound basalt lava flows. Although the Rockall Basin contains locally sourced lava fields attributable to Sequence T40, to date, no volcanic strata of Sequence T45 have been drilled.

Within the Rockall Basin, a number of large seamounts are present, which have been identified as being composed of Early Palaeogene intrusive igneous bodies. Three of these, Rosemary Bank, Hebrides Terrace and Anton Dohrn (Fig. 1), have been analysed from grab samples (O'Connor et al. 2000). These authors proposed that argon isotope $(\mathrm{Ar}) / \mathrm{Ar}$ dates obtained from basalts collected by grab samples supported a pulsing mantle plume model. Volcanism was considered to begin at $70 \pm 1$ $\mathrm{Ma}$, with pulses of activity recorded at $62 \mathrm{Ma}, 52 \mathrm{Ma}, 47 \mathrm{Ma}$, $42 \mathrm{Ma}$, which correspond with the Sullom and Horda formations of the equivalent Rockall Basin record. The dating of weathered basalts from grab samples with little geological context is problematical. Although these dates are statistically significant and included in the review of NAIP dating by Wilkinson et al. (2017), the nature of the material analysed introduces significant uncertainty with respect to the geological accuracy of the chronostratigraphical results. Currently, of these five dates, only $\sim 62$ $\mathrm{Ma}$ is supported by other geological evidence from the Rockall and Faroe-Shetland basins.

The Rosemary Bank, Hebrides Terrace and Anton Dohrn seamounts are included in seismic data surveys tied to well data (Schofield et al. 2018). The Anton Dohrn seamount currently rises above the sea floor, and is surrounded by Late Palaeogene and Neogene marine sedimentary rocks. Within the rock succession around the centre, bright, high-amplitude reflectors dipping away from the centre are correlative with a prograding volcaniclastic delta and lava field system penetrated by wells $132 / 6-1$ and 132/16-1 (Schofield et al. 2018, fig. 8). These are overlain by Eocene Balder Formation and Horda Formation sedimentary rocks, which onlap onto the Anton Dohrn structure, overstepping the potentially Sequence T36 volcanics/volcaniclastics. The Anton Dohrn centre was a topographic high during the deposition of these Sequence T40-Sequence T50 sedimentary rocks, much as it is today. Synbreakup volcanic activity on Anton Dohrn appears unlikely based on the available age dating and the evidence from seismic interpretaion. There is greater uncertainty over the initiation of this and other complexes given the lack of deep-well penetrations.

\section{Discussion}

Analysis of FSB and Rockall Basin strata has confirmed two main periods of volcanic activity (Fig. 20). Upper Danian to 


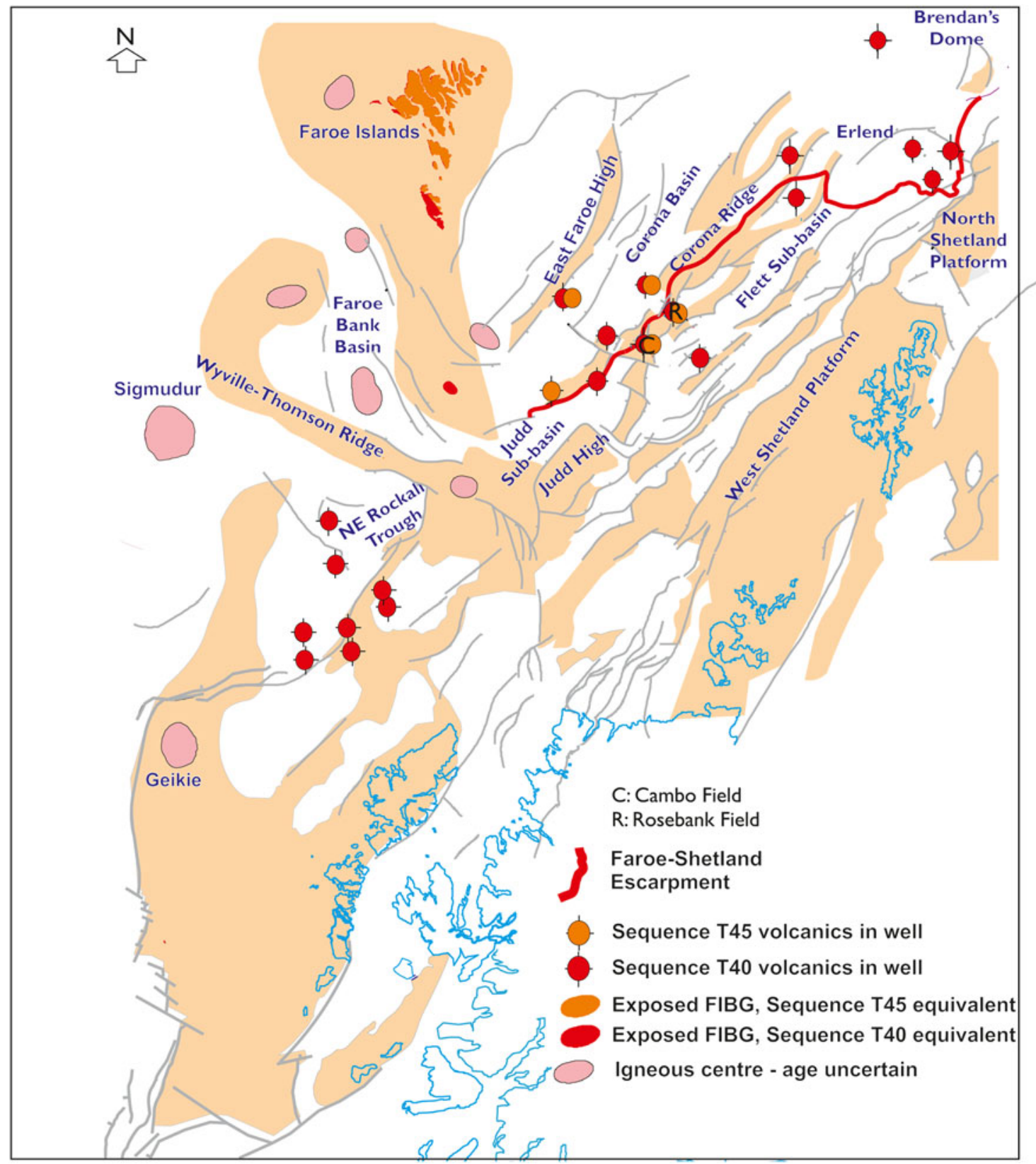

Figure 17 Map of syn-breakup volcanic rocks drilled in Faroe-Shetland and Rockall basin wells, exposed in the BPIP and on the exposed FIBG. The limit of the Faroe-Shetland Escarpment is also shown for reference. Volcanism is focused NE-SW across FSB and the Northeast Rockall Trough. Late syn-breakup, Sequence T45 extrusive volcanism is concentrated in the NW of the area, towards the location of the nascent North Atlantic Rift.

lower Thanetian pre-breakup volcanic activity corresponds to pyroclastic Phase 1 (Knox \& Morton 1988; Watson et al. 2017) and is composed of dominantly acidic ashes. In contrast, upper Thanetian to Ypresian syn-breakup activity includes the dominantly basaltic pyroclastic Phase 2 of Knox \& Morton (1988). The onset of pre-breakup volcanism was correlated with calcareous nannofossil zone NP4 (62.2 Ma, latest Danian; Ogg et al. 2016) by Nielsen et al. (2007). This date is comparable to geochronological ages for the oldest volcanics of the onshore BPIP (see Fig. 20), the Eigg Lava Formation and Muck Tuff (Eigg Lava $62.55 \pm 1 \mathrm{Ma}$ Ar-Ar sanidine tephra (Storey et al. 2007); Muck Tuff $61.74 \pm 1.76 \mathrm{Ma}$ sanidine tephra (Chambers et al. 2005)). The onset of volcanism was linked by Nielsen et al. (2007) to a change in tectonic regime from compressional to relaxational at $\sim 62.2 \mathrm{Ma}$ following cessation of $\mathrm{N}-\mathrm{S}$ convergence between Europe and Africa. Consequential rifting in the FSB gave rise to pre-breakup volcanic activity $(62.5-58.7 \mathrm{Ma})$, including the Sequence T36 lava fields (59.6-58.95 Ma). Within the Faroe-Shetland and Rockall basins, pre-breakup volcanism can be divided into four intervals (Fig. 20).

The oldest volcanic activity recorded in the Faroe-Shetland and Rockall basins is of upper Danian to lower Selandian age. Tephra records in Sequence T10 to Sequence T22 strata are coeval with the earliest volcanism recorded in the BPIP (Fig. 20), currently recorded from small exposures in Antrim and the Small Isles. Pillow lavas from the Mull Central Complex have also yielded a statistically valid date of $62.87 \pm 0.48 \mathrm{Ma}$ (Chambers et al. 2005; Wilkinson et al. 2017), indicating that they were erupted early in the evolution of the BPIP. This analysis was derived from a sample (SO17) included in a palaeomagnetic investigation of igneous rocks from Mull by Dagley et al. (1987). Sample SO17 was collected from pillow lavas within Mull Central Complex Centre 1 and described by these authors as 'texturally granoblastic, indicating recrystallization'. They highlight that the 'amygdales which once contained zeolites and chlorite have recrystallize to form plagioclase and pyroxene'. 


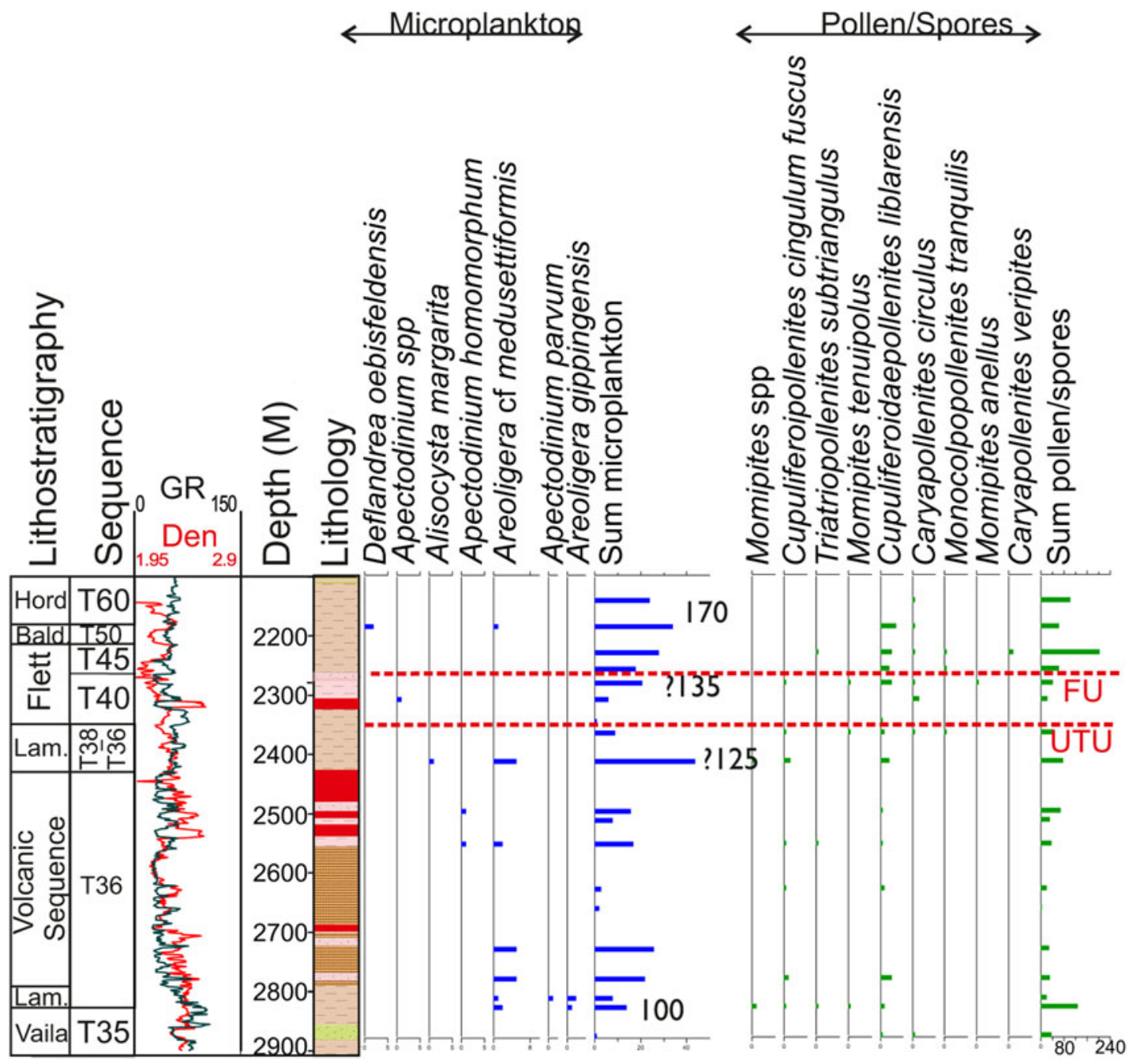

Figure 18 Well 164/28-1a. Positioned to the W of the West Lewis Ridge, this well recorded volcaniclastic and volcanic strata in Sequence T36. Occurrences of Alisocysta margarita and common Areoligera $c f$. medusettiformis in the marine shales overlying the volcanic succession indicate a lower Thanetian age. Above these, the Sequence T40 volcanic succession palynoflora contains Caryapollenites circulus and Apectodinium spp., with the overlying Sequence T45-Sequence T50 interval containing Deflandrea oebisfeldensis. All species palynomorph data displayed as square roots because of variable sample totals; only stratigraphically significant taxa are displayed. Sum pollen/spores, sum microplankton are plotted as raw data to illustrate intervals of variable recovery.

At best, the radiometric age derived from sample SO17 records a magmatic intrusion event, which caused contact metamorphism of these lavas.

The Mid Selandian interval during which sequences T25 to T31 Vaila Formation deposition took place, is characterised by an apparent absence of tephra in the Faroe-Shetland and Rockall basins. Isotope dating of the Rum early rhyodacite (Troll et al. 2008) and the Central Complex (Hamilton et al. 1998) indicate that activity did continue in the BPIP at the uplifted margin of the nascent North Atlantic Rift (Fig. 20). The absence of any tephra sourced from Rum in the Rockall Basin may be a consequence of it being adjacent to an area of few well penetrations. It may also be a result of prevailing westerly winds (Knox \& Morton 1988) transporting the ash to the SE. This apparent volcanic hiatus in the Faroe-Shetland and Rockall basins is followed by a period of increased tephra input into the basin, preserved in sequences T32-T35. This activity overlaps with the radiometric age errors of a felsic dyke in Mull Centre 3 (Loch Ba Dyke; Fig. 20), although the sampled dyke is a normally magnetised rock, which is most likely attributable to $\mathrm{C} 26 \mathrm{~N}$.

The extrusive lava fields and extensively distributed tephras attributed to Sequence T36 mark the peak of Selandian volcanism in the Rockall Basin and FSB. The upper Selandian Kettla Tuff
$\mathrm{Mb}$ and age-equivalent small lava flow fields are correlative with extrusive activity in the BPIP. The Skye Main Lava Series (SMLS) and apparently coeval Canna Lava Formation were erupted into eroded valleys in the Rum Western Granite (Emeleus 1997). The granite forms part of the Rum Central Complex, which has been dated as Selandian (Fig. 20; Hamilton et al. 1998). The SMLS lava field was subsequently intruded by the Thanetian, Cuillins Gabbro (Gabbro pegmatite $58.91 \pm 0.06 \mathrm{Ma}$; Hamilton et al. 1988). All of the SMLS lavas are of reversed magnetic polarity (Wilson et al. 1972), indicating lava field eruption prior to Chron 26N. In the $\sim 1$ Myr between intrusion of the Rum Central Complex and $\mathrm{C} 26 \mathrm{~N}$, significant uplift and erosion of the area was experienced followed by the eruption of the SMLS. Between 0.25 and $2.0 \mathrm{~km}$ of strata were thought to have been removed from above the Rum granodiorite (Troll et al. 2008), prior to eruption of the SMLS, indicating significant, rapid uplift and subsequent denudation of the basin's eastern flank.

Sequence T36 lava fields were located along the easterly margin of the active depocentres in the FSB and Rockall Basins with, currently, only a single example on the East Faroe High. Others appear as within-basin seamounts in the Rockall Basin. This spatial distribution and pattern of extrusive and pyroclastic volcanism was related to NNE-SSW-orientated early-stage rifting through the Faroe-Shetland and Rockall basins (Fig. 12). This 

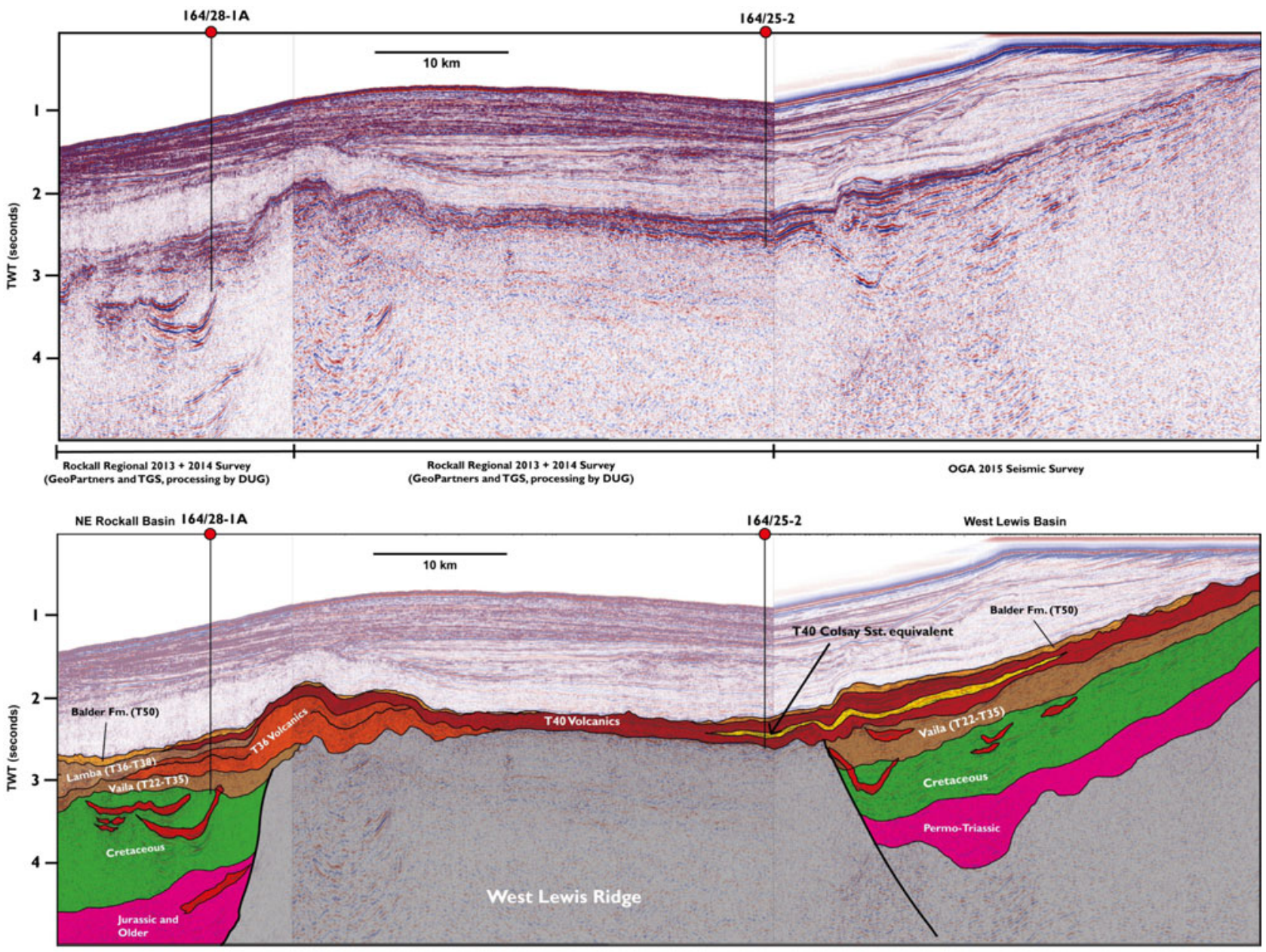

Figure 19 Rockall geoseismic correlation tied to well 164/28-1a (Fig. 18) and to well 164/25-2, the latter drilled through the eastern margin of the West Lewis Ridge (see Schofield et al. 2018). The Sequence T36 volcanics are apparently restricted to the western margin of the West Lewis Ridge and were probably sourced from a magmatic system related to the western bounding faults. The Sequence T40 volcaniclastic and volcanic strata, although thinner, are more extensive.

rifting is comparable in style to that seen along the Mid Ethiopian Rift (e.g., Keir et al. 2015; Siegberg et al. 2017).

Following cessation of Selandian to lower Thanetian extrusive volcanism in both the Faroe-Shetland and Rockall basins (Schofield et al. 2018), siliciclastic sedimentation continued, with deposition of the marine Lamba Formation (Sequence T38, Thanetian). Cessation of volcanic activity during the Thanetian (58.6-57 Ma) is considered to have occurred towards the close of a phase of relaxation related inversion in NW Europe (Nielsen et al. 2007). This inversion was inferred to relate to the ending of Africa-Europe convergence and was associated with a southerly migration of depocentres in the Sorgenfrei-Tornquist Zone of the eastern North Sea during this time (Nielsen et al. 2007). Resumption of sedimentation in the Faroe-Shetland and Rockall basins after $\sim 57 \mathrm{Ma}$ was reflected by a basin-wards shift in gross depositional environment from open-circulation shelf marine to variable salinity, restricted-circulation shallow-shelf marine and terrestrial facies at the base of the Flett Formation (Ellis \& Stoker 2014). In both basins, flood basalts, terrestrial or restricted-circulation shallow marine deposits are recorded resting unconformably on open-circulation marine shelf sediments of the Lamba or Vaila formations. This uplift is inferred to have resulted either from a resumption of thermal support from the magmatic system (e.g., Hartley et al. 2011), from intraplate rift-related stresses (Stoker et al. 2017), or the intrusion of several hundreds of meters in gross thickness of FSSC sills into Mesozoic sedimentary rocks (Schofield et al. 2015). Within the FSB, widespread hyaloclastite delta progradation and subsequent flood basalt eruptions were sourced from the FIBG in the NW, from $\mathrm{N}$ of the Ben Nevis structure (Millett et al. 2016; McLean et al. 2017), from near the Erlend Volcanic Centre (Jolley \& Bell 2002) and from localised fissures along the Corona Ridge and adjacent fault blocks (Schofield \& Jolley 2013; Hardman et al. 2018). Eruptive cyclicity was recorded within the Beinisvørð Formation of the FIBG (Jolley et al. 2012), with a total cessation of Beinisvørð Formation eruption at $\sim 55.85 \mathrm{Ma}$. This cessation of volcanic activity is recorded basin-wide from Kangerlussuaq (Ellis \& Stoker 2014) in the W, the Faroe Islands (Passey \& Jolley 2009), around the Erlend Volcanic complex in the N (Jolley \& Bell 2002) to the eastern margin of the Rockall Basin in the S (Schofield et al. 2018; Broadley et al. 2020).

Debate continues surrounding the age of the Beinisvørð Formation lavas of the FIBG, with Waagstein et al. (2002) reporting whole-rock potassium (K)-Ar and $\mathrm{Ar}-\mathrm{Ar}$ ages from altered basalt samples suggesting an onset of volcanism at ca. $58.8 \pm 0.5 \mathrm{Ma}$, whilst Storey et al. (2007) reported ages as old as 60.8 $\pm 1.2 \mathrm{Ma}$ for $\mathrm{Ar}-\mathrm{Ar}$ determinations on plagioclase separates from lavas penetrated by the Lopra 1/1A borehole (Storey et al. 2007; Fig. 20). For both the $\mathrm{K}-\mathrm{Ar}$ and $\mathrm{Ar}-\mathrm{Ar}$ isotopic dating methods, it has been widely reported that even small degrees of alteration (often petrographically invisible) can significantly affect age determinations (e.g., Hofmann et al. 2000; Kelley 2002; Baksi 2007; Baksi \& Reidel 2013; Cramer et al. 2013); therefore, challenges remain in terms of appraising the validity of low-K basaltic rocks that have undergone low-temperature metamorphism with clear evidence for the passage of heated hydrothermal fluids. In this regard, 


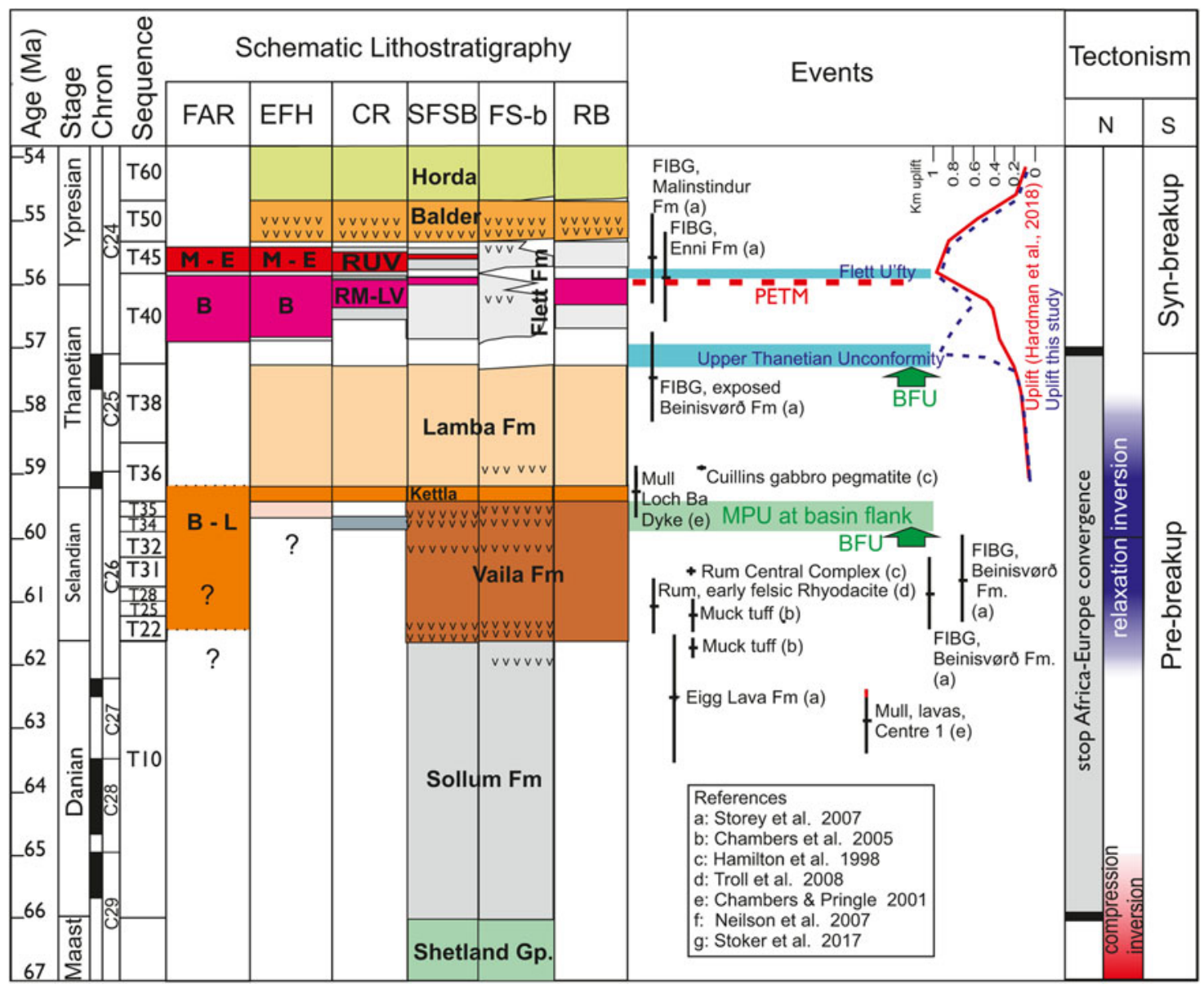

Figure 20 Synthesis panel showing the stratigraphical distribution volcanic and volcaniclastic rocks in the study area. Stratigraphical columns for locations are labelled as follows: FAR = Faroe Islands; EFH = East Faroe High; CR = Corona Ridge; SFSB = southern FSB; FSb = Flett Sub-basin; RB = Rockall Basin. Lithostratigraphical formations are coloured differently for clarity, and labelled as follows: B = Beinisvørð Formation; $\mathrm{M}=\mathrm{Malinstindur}$ Formation; $\mathrm{E}=$ Enni Formation; RM-LV = Rosebank Lower to Middle Volcanics; RUV = Rosebank Upper Volcanics; $\mathrm{v}=$ occurrences of volcanic ash in FSB and Rockall Basin sedimentary rocks. Radiometric dates for igneous centres and volcanic rocks which were determined to be statistically valid (Wilkinson et al. 2017) are shown in the Events column. Experimental errors on these dates are shown in black. Red bars indicate the restriction to these errors from age control imparted by the polarity of the host rock. The date for Mull Centre 1 pillow lavas is derived from a contact metamorphosed rock and included to highlight the potential age of intrusions in the Mull Central Complex. The red uplift curve is derived from Shaw Champion et al. (2008) and Hartley et al. (2011), as modified by Hardman et al. (2018). The maximum uplift post-dates the extrusion of the most voluminous flood basalt sequences and corresponds to a widespread unconformity and incision surface across the basin. The uplift curve of Hardman et al. (2018) is shown as a solid line, with the dashed line inferring the uplift at the Upper Thanetian Unconformity event demonstrated here. BFU = basin flank uplift episodes discussed in the text. Blue horizontal bars mark major basin unconformities. USE = upper Selandian Event marked by an expanded succession in the FSB and a correlative unconformity in the North Sea Basin. The right hand track ' $N$ ' in the diagram shows the correlation to tectonic events proposed by Nielsen et al. (2007) and those in track 'S' by Stoker et al. (2017).

Waagstein et al. (2002) clearly acknowledge increasing evidence for alteration of plagioclase phenocrysts with depth in the Lopra well: ' $[t]$ he plagioclase is generally clear and fresh-looking in the basalts from the upper part of the formation, but becomes increasingly clouded with microscopic inclusions and tiny fracture fillings downwards in the Lopra well' (p. 225).

A recent re-evaluation of the isotopic age dates for the North Atlantic discounted the Waagstein et al. (2002) ages, but appraised the Storey et al. (2007) ages as experimentally robust based on screening criteria, and recalculated them based on the updated timescale of Gradstein et al. (2012) to give an oldest age of $60.83 \pm 0.6 \mathrm{Ma}$ (Wilkinson et al. 2017; Fig. 20). These data imply continuous volcanism over a period of $>5 \mathrm{Myr}$. Biostratigraphic approaches outlined in Passey \& Jolley (2009) and Schofield \& Jolley (2013) attributed the Beinisvørð Formation to Sequence T40, indicating a younger age and shorter period of eruption $(<1.5 \mathrm{Myr})$. With new data provided by the analysis of the Brugdan wells on the East Faroe High and the associated seismic data interpretations presented here, a reappraisal of the discrepancy is timely.

The principal challenge for palynology in the Beinisvørð Formation lava field sections is that the sedimentary interbeds contain a poor marine dinocyst record due to deposition in dominantly sub-aerial to shallow-water environments. Pollen and spores from higher plants occur commonly, but stratigraphically significant assemblages are restricted to interbeds formed over longer time periods (Jolley et al. 2012). Constrained by the lower Ypresian, post-PETM terrestrial palynoflora of the overlying Prestfjall Formation (Passey \& Jolley 2009), the exposed Beinisvørð Formation contains palynofloras, including frequent Caryapollenites veripites, which indicate upper Sequence T40 equivalent strata. On the Faroe Islands, the subsurface Beinisvørð Formation is only penetrated by the Lopra 1/1A borehole. Drilled in two stages, samples recovered from drilling are limited to five cores of igneous lithologies and a suite of ditch cuttings. Samples taken from these ditch cuttings yielded palynofloras that lack age-diagnostic assemblages below $700 \mathrm{~m}$ (below sea level). However, because these assemblages are derived from ditch cuttings, cavings in the open hole may have extended this record down-section. Below $700 \mathrm{~m}$, the majority of the subsurface Beinisvørð Formation and the Lopra Formation has yielded palaeoenvironmental data, but no direct biostratigraphical age constraint. While the biostratigraphical and radiometric age determinations arrived at different conclusions, 
they both shared one aspect of interpretation - that the Beinisvørð and Lopra formations of the Faroe Islands area represented a single continuous period of volcanic activity, the difference between the approaches being the duration of that activity.

New information which helps to constrain the age of the southeastern margin of the FIBG is provided by the penetration of the succession in wells 6104/21-1 and 6104/21-2 (Figs 8, 11). These wells demonstrate the presence of the Thanetian to Selandian Lamba Formation and Vaila Formation marine shelf sedimentary rocks, including the Kettla Tuff $\mathrm{Mb}$, underneath the FIBG basalts. Absence of biostratigraphical constraint on the seismic and well log data has previously led to these sub-FIBG sediments and their hosted intrusions being regarded as part of the overlying lava pile (Olavsdottir et al. 2019). However, the occurrence of the Kettla Tuff $\mathrm{Mb}$ and underlying volcaniclastic, shallow marine sandstones of Sequence T35 in well 6104/21-2 (Figs 8, 11) is significant. The observed thickening northeastwards of this unit under the Sequence T40-Sequence T45 FIBG lava field (Fig. 9) indicates the presence of a Selandian volcanic succession on the East Faroe Platform, which potentially continues underneath the Faroe Islands. From seismic data (Fig. 9), Lamba Formation marine sedimentary rocks are observed to pinch out to the NW between the Selandian volcanic succession and the overlying Ypresian, Sequence T40 FIBG lava field. FIBG upper Thanetian to lower Ypresian volcanic rocks, therefore, rest unconformably on Selandian volcanic strata NE of the East Faroe High and potentially in the area of the Faroe Islands. Superposition of Palaeogene lava fields of different ages has been recognised within the Faroe-Shetland and Rockall basins (Lagavulin-Ben Nevis, McLean et al. 2017; Rockall Basin, Schofield et al. 2015; Figs 18,19$)$ and is probably more widespread (see also Anne Marie prospect on the Corona Ridge; Fig. 6). The presence of a Selandian volcanic succession unconformably overlain by an upper Thanetian to lower Ypresian lava field is concordant with the radiometric dates of Storey et al. (2007). Selandian radiometric ages from the Lopra $1 / 1 \mathrm{~A}$ borehole $(60.63 \pm 0.70 \mathrm{Ma}$; $60.83 \pm 0.60 \mathrm{Ma})$ contrast with a radiometric age $(57.49 \pm 0.60$ $\mathrm{Ma}$ ) indicating upper Thanetian eruption of the exposed Beinisvørð Formation.

In the FSB, activity resumed in lower Sequence T45 (Ypresian, $\sim 55.8 \mathrm{Ma}$ ) on the Corona Ridge, with the eruption of dominantly fissure-fed flow fields (Schofield \& Jolley 2013). Thicker Sequence T45 lavas were extruded, dominantly from low-angle shield volcanoes to the $\mathrm{W}$ in two large-scale cycles forming the Malinstindur and Enni formations of the FIBG (Passey \& Jolley 2009; Millett et al. 2017). Equivalent Ypresian flow fields prograded towards the E, although those drilled on the Corona Ridge were locally erupted (Schofield \& Jolley 2013; Hardman et al. 2017; Poppitt et al. 2018). These localsourced flow fields of both Sequence T40 and Sequence T45, in particular those of the Corona Ridge, have been included within the mapped extent of the Faroe-Shetland Escarpment (Fig. 1). Interpreted as a hyaloclastite delta front (Passey \& Hitchen 2011), previously published and new evidence presented here indicates that this feature is composed of flow fields of different source areas and ages, including some intrusive sheets.

\section{Unconformities}

The Selandian to lower Ypresian interval of the Faroe-Shetland and Rockall basins is recognised as including three major unconformities (e.g., Stoker et al. 2017). The oldest Danian-Selandian Unconformity is apparently unrelated to volcanism in the NAIP (Stoker et al. 2017). However, the Mid Palaeogene Unconformity and Flett Unconformity have been recorded to be coincidental with syn-breakup and post-breakup volcanism.

Coeval with the uplift and erosion of the Inner Hebrides, a Mid Palaeocene unconformity (Stoker et al. 2017; Olavsdottir et al. 2019) has been recorded in the FSB and tied to the upper boundary of Sequence T35. Well and seismic data do not provide evidence of a significant unconformity within the basin at this point (Figs 7, 9), but do indicate the presence of an expanded section between Sequence T34 and the top of Sequence T36. Within the North Sea Basin, the Kettla Tuff Mb equivalent Glamis Tuff $\mathrm{Mb}$ occurs below the acme of Areoligera gippingensis and above the first downhole influx of Palaeoperidinium pyrophrum (Jolley 1998; Vieira et al. 2020). In the FSB, the Kettla Tuff Mb (at the base of Sequence T36) is significantly higher up the succession than the first downhole occurrence of common P. pyrophorum. This occurs at the upper limit of Sequence T31. The interval equivalent to sequences T32, T34 and T35 is, therefore, highly condensed or missing in the North Sea Basin. This is potentially a result of extensional pre-breakup subsidence in the FSB and a lack of accommodation space on the uplifted flank in the North Sea Basin. The presence of an expanded succession in the FSB is supported by the tentative identification of a negative carbon isotope excursion (Fig. 3) in Sequence T34, a potential record of the Selandian-Thanetian Transitional Event (STTE; Barnet et al. 2019). This event is recorded as occurring immediately below Chron $26 \mathrm{~N}$ in Tethys (Gubbio section; Coccioni et al. 2012) and in the lower latitude North Atlantic (Zumia section; Storme 2012).

Confusion has been centred around the stratigraphical position and extent of the well-documented Flett Unconformity (Shaw Champion et al. 2008; Hartley et al. 2011; Stoker et al. 2017). In the Judd Sub-basin, a NW-trending, incised dendritic drainage system was deeply eroded during Flett Formation times into the underlying Lamba Formation. This drainage system has been attributed to transient uplift associated with the impact of the Iceland Plume in the region (Shaw Champion et al. 2008), tied to pulsing of the mantle plume around the PETM. These authors linked the erosion surface to the onset of Flett Formation deposition (e.g., Stoker et al. 2017), or to the PETM (Hartley et al. 2011). However, these interpretations have been significantly hampered by a lack of biostratigraphical control in an interval where low-salinity marine and terrestrial palynofloras are dominant.

Wells penetrating the most complete successions in interchannel zones of the Judd Sub-basin dendritic system (e.g., 204/22-2 and 204/25a-3; see supplementary data S2) include sedimentary rock units deposited in fluvially dominated facies during uppermost Sequence T40 (equivalent to LAZ Rc6Rc7; Schofield \& Jolley 2013; Fig. 2). These inter-dendritic channel strata are unconformably overlain by terrestrial to shallow marine, Sequence T45 (Flett Formation Unit F2b-F3) strata. Where the dendritic channels are most deeply incised (into Sequence T38, Lamba Formation), the oldest post-erosion channel fill is attributable to Flett Formation Unit F2a (e.g., 204/191; see supplementary data S2). While these data support uplift and incision of the Judd Sub-basin area, it is clear that the erosive phase identified by previous authors occurred after the deposition of uppermost Sequence T40 sediments - that is, within the Flett Formation, not at the onset of its deposition.

Within the Judd Sub-basin, uppermost Flett Formation Unit F1b strata rest unconformably on Sequence T38 marine Lamba Formation sediments (supplementary data S2). These strata are, in turn, locally eroded and overlain by Sequence T45 Flett Formation sedimentary rocks. This succession highlights the presence of a second, older unconformity. Lack of effective biostratigraphical control has resulted in these two erosion surfaces being amalgamated. 
Further evidence of the sub Flett Formation (sub Sequence T40) unconformity, here termed the Upper Thanetian Unconformity, is recorded in the geoseismic interpretation of the southern FSB presented here (Fig. 7) and is also present in interpreted seismic lines presented by Hardman et al. (2018; Fig. 2). Here, the Upper Thanetian Unconformity is evident as an uplifted and deeply eroded surface, dissecting the uppermost Lamba Formation Sequence T38. The most deeply eroded areas provided accommodation space for the deposition of shallow marine to terrestrial Sequence T40 sedimentation (e.g., 6005/15-1; Fig. 3). In this well, the uppermost Flett Formation Unit 1b, which includes the youngest PETM excursion and recovery phase, is eroded by the subsequent Flett Unconformity. In this case, shallow marine sediments of Flett Formation Unit F2b-F3 were deposited on the Flett Unconformity surface (Fig. 3).

Within the Judd Sub-basin, the Flett Unconformity dendritic drainage system was initiated at the boundary between Flett Formation units F1b and F2a. How much of this system was inherited from the more extensive Upper Thanetian Unconformity surface is currently undetermined, as is the impact of the amalgamation of these surfaces on estimations of uplift. The development of the dendritic Flett Unconformity in the Judd Sub-basin has been attributed to a greater degree of uplift in the $\mathrm{S}$ of the FSB (Stoker et al. 2017). This appears to be a perception driven by the absence of three-dimensional seismic data in the centre and $\mathrm{N}$ of the FSB. However, two-dimensional seismic data and associated well penetrations clearly identify the presence of a significant correlative erosion surface in the Flett Sub-basin to the $\mathrm{N}$ and in the $\mathrm{S}$ of the Corona Basin (Fig. 7). The change from open-circulation marine sedimentation to organic rich, restricted-circulation shallow marine to terrestrial sedimentation was noted at this boundary by Ellis \& Stoker (2014). This change is mirrored at the correlative unconformity surface in the North $\mathrm{Sea}$, where the Lista Formation is overlain by the Forties $\mathrm{Mb}$ of the Sele Formation. Similarly, shift to transitional zone facies is recorded as far S as southeastern England, where the Thanet Sands/Ormesby Clay formations are overlain by Lambeth Group (Ellison et al. 1994).

The timing of uplift associated with the Flett Unconformity has been discussed by Hardman et al. (2018), who reported evidence for a slow decline in thermal support following maximum uplift (Fig. 20) during deposition of the Flett Formation. Maximum incision on the palaeo-shelf and, thus, maximum uplift has been proposed to have occurred at the Sequence T40-Sequence T45 boundary (Fig. 20). This was coincident with the slow down and cessation of eruption of the widespread Sequence T40 lava fields, including the exposed Beinisvorð Formation of the FIBG. Thermal support from magmatism is demonstrated to have continued after the maximum effusion of flood basalts in the Beinisvorð Formation, and to occur within the Colsay 1 sedimentary rock succession of the Corona Ridge (Figs 3, 15). The cessation of high-volume flood basalt eruption and switch to lower-volume intrusion and eruptions at this time is attributed to a switch to higher-level melts and intrusions.

Identification of the Upper Thanetian and Flett unconformities sheds light on the timing of uplift in the Faroe-Shetland and Rockall basins. The most prolonged gap in the stratigraphical record coincides with the incision of the most prominent erosion surface at the upper Thanetian Sequence T38-Sequence T40 boundary. Calculations of uplift at the younger Flett Unconformity by Shaw Champion et al. (2008) are, therefore, based on an inherited drainage system modified by later Ypresian erosion at the Sequence T40-Sequence T45 boundary. Maximum uplift of the FSB occurred at the Upper Thanetian Unconformity, immediately preceding the onset of widespread flood basalt eruption in Sequence T40 (Fig. 20) and coincidental with at least one phase of FSSC intrusion in the Flett Sub-basin (Fig. 16).

\section{Conclusions}

Integration of biostratigraphical, wireline log and geophysical data has identified two periods of eruption in the Faroe-Shetland and Rockall Basins. These periods have different orientations and foci, resulting from them being responses to different processes.

The first period is pre-breakup. Volcanism occurred as a consequence of a rifting episode driven by a relaxation of intra-plate deformation in Europe following the cessation of convergence of Africa and Europe at $62 \mathrm{Ma}$. This early rift was orientated SSWNNE on a Cretaceous trend and parallel to the continental margin in the Rockall Basin and FSB. Volcanic activity was initially concentrated at basin flank structures, under the present Faroe Islands and within the Rockall Basin at seamounts. Structural lineaments linked the basin volcanism to rift-flank volcanism of the BPIP, focussed at large igneous centres. Some of these central complexes (e.g., Rum, Mull) were uplifted and rapidly eroded later during the pre-breakup period, at a time when additional accommodation space was developed in the offshore sedimentary basins. This is interpreted as a $\sim 61 \mathrm{Ma}$ phase of basin flank uplift, amplified by a shallowing of melt depth and associated granitic intrusions (Hole et al. 2015). At the non-volcanic margins of the FSB, this late uplift phase is potentially associated with the Mid Palaeocene Unconformity of some authors (e.g., Stoker et al. 2017). Only one rift-flank flow field has been identified to date on the western side of the pre-breakup basin, against many on the eastern flank and within the basin. These stretch from the Rockall Basin to the Ben Nevis structure. This could suggest that this rift was asymmetrical, but much of the potential evidence lies beneath the extrusive volcanic rocks of the synbreakup eruptions. Cessation of pre-breakup eruption is correlated to the cessation of intra-European plate relaxation inversion (Nielsen et al. 2007).

The second period of eruption is syn-breakup. The most geographically widespread phase of flood basalt eruptions initiated following a major eastern margin North Atlantic uplift event, which resulted in the Upper Thanetian Unconformity in the Rockall Basin and FSB. Initial high-volume extrusive igneous successions were focussed to the $\mathrm{W}$ of the FSB. In the centre and $\mathrm{E}$ of the basin, separate eruption loci developed along preexisting lineaments either as fissure or point-sourced lava fields. With shallowing of melting at the end of the first stage, a granitic centre developed on Skye (Eastern Red Hills Granites) and thermal support was maintained in the basin beyond the end of highvolume flood basalt eruption.

Reactivation and further erosion of the Upper Thanetian Unconformity surface at $\sim 55.85 \mathrm{Ma}$ was linked to formation of the Flett Unconformity. Subsequent slow basin subsidence (Hardman et al. 2018) resulted in deposition of shallow marine to terrestrial sedimentary successions, infilling the eroded surface. These interdigitated with the syn-breakup lava fields developed at the basin centre and western margin. The north-westerly shift of eruption focus and the eruption of mid ocean ridge basalt (MORB)-type lavas in the younger stages of the syn-breakup reflects the emplacement of oceanic crust in the nascent North Atlantic Rift prior to flooding of the rift and eruption of the widespread Balder Formation ashes.

Over the Palaeogene, Stoker et al. (2017) present evidence that the opening of the NE Atlantic is not simple rift to post-rift subsidence, but a long-term record of tectonic instability and vertical crustal motions into the Eocene. The evidence presented here confirms that a Danian-Thanetian nascent rift developed on a Cretaceous lineament along the Rockall Basin and FSB as a 
result of changes in intra-plate stress regimes in Europe. Clarification of the relationship of syn-breakup to the record of regional uplift highlights that the oldest, highest amplitude uplift (which formed the Upper Thanetian Unconformity) occurred prior to, or at the onset of, syn-breakup magmatism. Changes in gross depositional environment across the unconformity, noted earlier by Ellis \& Stoker (2014), are seen over the 1000 $\mathrm{km}$ from the Faroe-Shetland to the London Basin, all signifying uplift, erosion and subsequent dominance by terrestrial and restricted marine depositional systems. Regional uplift of this magnitude is likely to be a reflection of changes in tectonic regime, exceeding the magnitude of the expected effects of a mantle plume.

\section{Supplementary material}

Supplementary material is available online at https://doi.org/10. $1017 / \mathrm{S} 1755691021000037$.

\section{Acknowledgements}

The authors would like to thank Simon Kelley for comments on an earlier draft of the manuscript and for discussions on radiometric age dating. Dougal Jerram and John Faithfull are thanked for their constructive and helpful comments on the manuscript. PGS are thanked for permission to publish FSB MegaSurvey Plus data shown in Figures 6 and 8. PGS and TGS are thanked for permission to publish seismic data from the FSB2012 GeoStreamer survey also shown in Figure 6. Data used in Figure 19 are courtesy of GeoPartners and TGS, processing by DUG. IHS Kingdom Suite and Schlumberger Petrel Software are thanked for their donation of academic licenses to the University of Aberdeen.

\section{References}

Ali, J. R. \& Jolley, D. W. 1996. Biostratigraphically constrained magnetostratigraphy of the 33 Paleocene and Early Eocene of the Anglo - Belgium - Paris Basin. In Knox, R. W. O'B., Corfield, R. \& Dunay, R. E. (eds) Correlation of the Early Paleogene in northwest Europe, 129-44. London: Geological Society of London, Special Publication 101.

Angkasa, S. S., Jerram, D. A., Millett, J. M., Svensen, H. H., Planke, S., Taylor, R. A., Schofield, N. \& Howell, J. 2017. Mafic intrusions, hydrothermal venting, and the basalt-sediment transition: linking onshore and offshore examples from the North Atlantic igneous province. Interpretation 5, SK83-101.

Archer, S. G., Bergman, S. C., Iliffe, J., Murphy, C. M. \& Thornton, M. 2005. Palaeogene igneous rocks reveal new insights into the geodynamic evolution and petroleum potential of the Rockall Trough, NE Atlantic Margin. Basin Research 17, 171-201.

Baksi, A. K. 2007. A quantitative tool for detecting alteration in undisturbed rocks and minerals - I: water, chemical weathering, and atmospheric argon. In Foulger, G. R. \& Jurdy, D. M. (eds) Plates, plumes and planetary processes, 285-303. Boulder, Colorado, USA: Geological Society of America, Special Papers, 388.

Baksi, A. K. \& Reidel, S.P. 2013. Timing and duration of volcanism in the Columbia River Basalt Group: a review of existing radiometric data and new constraints on the age of the Steens through Wanapum Basalt extrusion. The Columbia River Flood Basalt Province: Geological Society of America Special Papers 497, 67-85.

Barnet, J. S. K., Littler, K., Westerhold, T., Kroon, D., Leng, M. J., Bailey, L., Rohl U. \& Zachos, J. C., 2019. A high-fidelity benthic stable isotope record of Cretaceous-Early Eocene climate change and carbon-cycling. Paleoceanography and Paleoclimatology 34, 672-91.

Beerling, D. J. \& Jolley, D. W. 1998. Fossil plants record an atmospheric ${ }^{12} \mathrm{CO}_{2}$ and temperature spike across the Paleocene-Eocene transition in NW Europe. Journal of the Geological Society, London 155, 591-94.

Broadley, L., Schofield, N., Jolley, D., Howell, J. \& Underhill, J. 2020. UK Rockall prospectivity: re-awakening exploration in a frontier basin. Petroleum Geoscience 26, 247-71.
Chambers, L. M., Pringle, M. S. \& Parrish, R. R. 2005. Rapid formation of the Small Isles Tertiary centre constrained by precise ${ }^{40} \mathrm{Ar} /{ }^{39} \mathrm{Ar}$ and $\mathrm{U}-\mathrm{Pb}$ ages. Lithos 79, 367-84.

Coccioni, R., Bancalà, G., Catanzarit, R., Fornaciari, E., Frontalini, F., Giusberti, L., Jovane, L., Luciani, V., Savian, J. \& Sprovieri, M. 2012. An integrated stratigraphic record of the Palaeocene-Lower Eocene at Gubbio (Italy): new insights into the Early Palaeogene hyperthermals and carbon isotope excursions: Early Palaeogene integrated stratigraphy at Gubbio. Terra Nova 24, 380-86.

Cramer, E. L., Sherlock, S. C., Halton, A. M., Blake, S., Barry, T.L., Kelley, S. P. \& Jolley, D. W. 2013. Which age is the true age? Unravelling within-flow 40Ar/39Ar age variations in Faroe Islands basalt lavas. Mineralogical Magazine 77, 294.

Crouch, E. M., Dickens, G. R., Brinkhuis, H., Aubry, M.-P., Hollis, C. J., Rogers, K. M. \& Visscher, H. 2003. The Apectodinium Acme and terrestrial discharge during the Paleocene-Eocene thermal maximum: new palynological, geochemical and calcareous nannoplankton observations at Tawanui, New Zealand. Palaeogeography, Palaeoclimatology, Palaeoecology 194, 387-403.

Dagley, P., Mussett, A. E. \& Skelhorn, R. R. 1987. Polarity, stratigraphy and duration of the Tertiary igneous activity of Mull, Scotland. Journal of the Geological Society, London 144, 985-96.

Ebdon, C. C., Granger, P. J., Johnson, H. D. \& Evans A. M. 1995. Early tertiary evolution and stratigraphy of the Faeroe-Shetland Basin: implications for hydrocarbon prospectivity. In Scrutton, R. A., Stoker, M., Shimmield, G. B. \& Tudhope, A. W. (eds) Sedimentation and palaeoceanography of the North Atlantic region, 51-69. London: Geological Society of London, Special Publication 90.

Eidesgaard, O. R. \& Ziska, H. 2015. The Kettla Member; an overview from the Faroe Shetland Basin. In Eidesgaard, O. R. \& Ziska, H. (eds) Faroe Islands Exploration conference: proceedings of the 4th conference. Torshavn: Annals Societatis Scientiarum Faerensis, 2644. Supplementum 64.

Eldrett, J., Efthymios, T., Davis, C., McKie, T., Vieira, M., Osterloff, P. \& Sanderson, T. 2015. Sedimentological evolution of Sele Formation deep-marine depositional systems of the Central North Sea. In McKie, T., Rose, P. T. S., Hartley, A. J., Jones, D. W. \& Armstrong, T. L. (eds) Tertiary deep-marine reservoirs of the North Sea, 63-98. London: Geological Society London, Special Publication 403.

Ellis, D., Jolley, D. W., Passey, S. R. Bell, B. R. 2009. Transfer zones: the application of new geological information from the Faroe Islands to the offshore exploration of intra basalt and sub basalt prospects. In Varming, T. et al. (eds) Faroe Islands Exploration conference: proceedings of the 2nd conference, 205-26. Tórshavn.

Ellis, D. \& Stoker, M. 2014. The Faroe-Shetland Basin: a regional perspective from the Paleocene to the present day and its relationship to the opening of the North Atlantic Ocean. In Cannon, S. J. C. \& Ellis, D. (eds) Hydrocarbon exploration to exploitation West of Shetlands, 11-31. London: Geological Society, London, Special Publications 397.

Ellison, R. A., Knox, R. W. O’B., Jolley, D. W. \& King, C. 1994. A revision of the lithostratigraphical classification of the early Palaeogene strata of the London Basin and East Anglia. Proceedings of the Geologists' Association 105, 187-97.

Emeleus, C. H. 1997. Geology of Rum and adjacent islands. Memoir of the British Geological Survey, Sheet 60, (Scotland) HMSO.

Emeleus, C. H. \& Bell, B. R. 2005. British Regional geology: the Palaeogene volcanic districts of Scotland. 4th edn. Nottingham: British Geological Survey, 214 pp.

Gallagher, J. W. \& Drumgoole, P. W. 2007. Exploring below the basalt, offshore Faroes: a case history of sub-basalt imaging. Petroleum Geoscience 13, 213-25.

Ganerød, M., Smethurst, M. A., Torsvik, T. H., Prestvik, T., Rousse, S., McKenna, C., van Hinsbergen, D. J. J. \& Hendriks, B. W. H. 2010. The North Atlantic Igneous Province reconstructed and its relation to the Plume Generation Zone: the Antrim Lava Group revisited. Geophysical Journal International 182, 183-202.

Gradstein, F.M., Ogg, J.G., Schmitz, M.D. \& Ogg, G.M. 2012. The geological time scale 2012. Elsevier, $1144 \mathrm{pp}$.

Grove, C. 2013. Submarine hydrothermal vent complexes in the Paleocene of the Faroe-Shetland Basin: insights from three-dimensional seismic and petrographical data. Geology 41, 71-74.

Hamilton, M. A., Pearson, D. G., Thompson, R. N., Kelley, S. P. \& Emeleus, C. H. 1998. Rapid eruption of Skye lavas inferred from precise $\mathrm{U}-\mathrm{Pb}$ and $\mathrm{Ar}-\mathrm{Ar}$ dating on the Rum and Cuillin plutonic complexes. Nature 394, 260-62.

Hardman, J., Schofield, N., Jolley, D. W., Hartley, A., Holford, S. \& Watson, D. 2017. Controls on the distribution of volcanism and intra-basaltic sediments in the Cambo-Rosebank region, west of Shetland. Petroleum Geoscience, 19pp. doi: 10.1144/petgeo2017061 . 
Hardman, J. P. A., Schofield, N., Jolley, D. W., Holford, S. P., Hartley, A. J., Morse, S., Underhill, J., Watson, D. A. \& Zimmer, E. H. 2018 Prolonged dynamic support from the Icelandic plume of the NE Atlantic margin. Journal of the Geological Society 175, 396.

Hartley, R. A., Roberts, G. C, White, N \& Richardson, C. 2011. Transient convective uplift of an ancient buried landscape. Nature Geoscience 4, 562-65.

Heilmann-Clausen, C. 1985. Dinoflagellate stratigraphy of the uppermost Danian to Ypresian in the Viborg I borehole, central Jylland, Denmark. Danmarks Geologiske Undersogelse, Serie A, 7, 1-69, pl $1-15$.

Helland-Hansen, D. 2009. Rosebank - challenges to development from a subsurface perspective. In Varming, T. \& Ziska, H. (eds) Faroe Islands Exploration conference: proceedings of the 2nd conference, 63-78. Færoensis: Annales Societatis Scientiarum. Supplementum 50.

Hofmann, C., Féraud, G. \& Courtillot, V. $2000 .{ }^{40} \mathrm{Ar} /{ }^{39} \mathrm{Ar}$ Dating of mineral separates and whole rocks from the Western Ghats lava pile: further constraints on duration and age of the Deccan Traps. Earth and Planetary Science Letters 180, 13-27.

Hole, M. J., Millett, J. M., Rogers, N. W. \& Jolley, D. W. 2015. Rifting and mafic magmatism in the Hebridean basins. Journal of the Geological Society, London 172, 218-36.

Jerram, D. A., Single, R. T., Hobbs, R. W. \& Nelson, C. E. 2009. Understanding the offshore flood basalt sequence using onshore volcanic facies analogues: an example from the Faroe Shetland basin. Geological Magazine 146, 353-67.

Jolley, D. W. 1996. The earliest Eocene sediments of eastern England; an ultra high resolution palynological correlation. In Knox, R. W. O'B. Corfield, R. \& Dunay, R. E. (eds) Correlation of the Early Paleogene in northwest Europe, 219-54. London: Geological Society of London, Special Publication, 101.

Jolley, D. W. 1998, Palynostratigraphy and depositional history of the Palaeocene Ormesby/Thanet depositional sequence set in southeastern England and its correlation with continental west Europe and the Lista Formation, North Sea. Review of Palaeobotany and Palynology 99, 265-315.

Jolley, D. W. 2009. Palynofloral evidence for the onset and cessation of eruption of the Faroe Islands lava field. In Varming, T. et al. (eds) Faroe Islands Exploration conference: proceedings of the 2nd conference, 156-73. Tórshavn.

Jolley, D. W., Morton, A. C. \& Prince, I. P. 2005. Volcanogenic impact on phytogeography and sediment dispersal patterns in the NE Atlantic. In Dore A. G. \& Vining, B. A. (eds) Petroleum geology: $N W$ Europe and global perspectives, proceedings of the 6th petroleum geology conference, 969-75. London: Geological Society.

Jolley, D. W., Widdowson, M. \& Self, S. M. 2008. Volcanogenic nutrient fluxes and plant ecosystems in Large Igneous Provinces. An example from the Columbia River Basalt Group. Journal of the Geological Society, London 165, 955-66.

Jolley, D. W., Passey, S., Hole, M. \& Millet, J. 2012. Basaltic melt fractionation drives plant ecosystem dynamics. Geological Society, London 163, 709-11.

Jolley, D. W. \& Bell, B. R. 2002. Genesis and age of the Erlend Volcano, NE Atlantic Margin. In Jolley, D. W. \& Bell, B. R. (eds) The North Atlantic igneous province: stratigraphy, tectonic, volcanic and magmatic processes, 95-110. Geological Society, London, Special Publication 197.

Jolley, D. W. \& Morton, A. C. 2007. Understanding basin sedimentary provenance: evidence from allied phytogeographic and heavy mineral analysis of the Paleocene of the NE Atlantic. Journal of the Geological Society, London 164, 553-64.

Jolley, D. W. \& Whitham, A. 2004. A stratigraphical and palaeoenvironmental analysis of the sub-basaltic Palaeogene sediments of east Greenland. Petroleum Geoscience 10, 53-60.

Jolley, D. W. \& Widdowson, M. 2005. North Atlantic rift eruptions drive Eocene climate cooling. Lithos 79, 355-66.

Jones, M. T., Augland, L. E., Shephard, G. E., Burgess, S. D., Eliassen, G. T., Jochmann, M. M. M., Friis, B., Jerram, D. A., Planke, S. \& Svensen, H. H. 2017. Constraining shifts in North Atlantic plate motions during the Palaeocene by U-Pb dating of Svalbard tephra layers. Nature, Scientific Reports 7, 6822.

Keir, D., Bastow, I. D. \& Corti, G. 2015. The origin of along-rift variations in faulting and magmatism in the Ethiopian rift. Tectonics 34, 464-77.

Kelley, S. 2002. K-Ar and Ar-Ar dating. Reviews in Mineralogy and Geochemistry 47, 785-818.

Kender, S., Stephenson, M. H., Riding, J. B., Leng, M. J., Knox, R. W. O'B., Peck, V. L., Kendrick, C. P., Ellis, M. A., Vane, C. H. \& Jamieson, R. 2012. Marine and terrestrial environmental changes in NW Europe preceding carbon release at the Paleocene-Eocene transition. Earth and Planetary Science Letters 353-354, 108-20.
Knox, R. W. O'B. \& Holloway, S. 1992. 1.Paleogene of the Central and Northern North Sea. In Knox, R. W. O’B. \& Cordey, W. G. (eds) Lithostratigraphic nomenclature of the UK North Sea. British Geological Survey, Nottingham, 133pp.

Knox, R. W. O'B. \& Morton, A. C. 1988. The record of early Tertiary N Atlantic volcanism in sediments of the North Sea Basin. In Morton, A. C. \& Parson, L. M. (eds) Early Tertiary volcanism and the opening of the NE Atlantic, 407-19. London: Geological Society Special Publications, 39 .

McLean, C. E., Schofield, N., Brown, D. J., Jolley, D. W. \& Reid, A. 2017 3D Seismic imaging of the shallow plumbing system beneath the Ben Nevis Monogenetic Volcanic Field: Faroe-Shetland Basin. Journal of the Geological Society 174, 468-85.

Millett, J. M., Hole, M. J. \& Jolley, D. W. 2014. A fresh approach to ditch cutting analysis as an aid to exploration in areas affected by large igneous province (LIP) volcanism. In Cannon, S. J. C. \& Ellis, D. (eds) Hydrocarbon exploration to exploitation West of Shetlands, 14 pp. London: Geological Society, London. Special Publications 397, http://dx.doi.org/10.1144/SP397.2.

Millett, J. M., Hole, M. J., Jolley, D. W., Schofield, N. \& Campbell, E. 2016. Frontier exploration and the North Atlantic Igneous Province: new insights from a $2.6 \mathrm{~km}$ offshore volcanic sequence in the NE Faroe-Shetland Basin. Journal of the Geological Society 173, $320-36$.

Millett, J. M., Hole, M. J., Jolley, D. W. \& Passey, S. R. 2017. Geochemical stratigraphy and correlation within large igneous provinces: the final preserved stages of the Faroe Islands Basalt Group. Lithos 28687, $1-15$.

Morton, A. C., Evans, D., Harland, R., King, C. \& Ritchie, J. D. 1988 Volcanic ash in a cored borehole W of the Shetland Islands: evidence for Selandian (late Paleocene) volcanism in the Faroes region. In Morton, A. C. \& Parson, L. M. (eds) Early Tertiary volcanism and the opening of the NE Atlantic, 263-69. London: Geological Society of London, Special Publications 39.

Mudge, D. C. 2015. Regional controls on Lower Tertiary sandstone distribution in the North Sea and NE Atlantic margin basins. In McKie, T., Rose, P. T. S., Hartley, A. J., Jones, D. W. \& Armstrong T. L. (eds) Tertiary deep marine reservoirs of the North Sea Region, 17-42. London: Geological Society London, Special Publications 403 .

Mudge, D. C. \& Bujak, J. P. 2001. Biostratigraphical evidence for evolving palaeoenvironments in the Lower Paleogene of the FaeroeShetland Basin. Marine \& Petroleum Geology 18, 557-90.

Naylor, P. H., Bell, B. R. Jolley, D. W. Durnall, P. \& Fredstead, R. 1999. Palaeogene magmatism in the Faeroe-Shetland Basin: influences on uplift history and sedimentation. In Fleet \& Boldy, Petroleum Geology of Northwest Europe, Proceedings of the 5th Conference, Geological Society of London, 545-58.

Nielsen, S. B, Stephenson, R. \& Thomsen, E. 2007. Dynamics of midPalaeocene North Atlantic rifting linked with European intra-plate deformations. Nature 450, 1071-74

Nelson, C. E., Jerram, D. A., Single, R. T. \& Hobbs, R. W. 2009. Understanding the facies architecture of flood basalts and volcanic rifted margins and its effects on geophysical properties. Proceedings of the 2nd Faroe Islands Exploration Conference. Annales Societatis Scientiarum Færoensis, Supplimentum 50, 84-103.

O'Connor, J. M., Stoffers, P., Wijbrans, J. R., Shannon, P. M. \& Morrissey, T. 2000. Evidence from episodic seamount volcanism for pulsing of the Iceland plume in the past 70 Myr. Nature 408, 954-58.

Ogg, J. G., Ogg, G. \& Gradstein, F. M. 2016. A concise geologic time scale 2016. Amsterdam: Elsevier, $250 \mathrm{pp}$

Olavsdottir, J., Stoker, M. S., Boldreel, L. O., Andersen, M. S. \& Eidesgaard, O. R. 2019. Seismic-stratigraphic constraints on the age of the Faroe Islands Basalt Group, Faroe-Shetland region, Northeast Atlantic Ocean. Basin Research 31, 841-65.

Parsons, A. J., Whitham, A. G., Kelly, S. R. A., Vautravers, B. P. H., Dalton, T. J. S., Andrews, S. D., Pickles, C. S., Strogen, D. P., Braham, W., Jolley, D. W. \& Gregory, F. J. 2017. Structural evolution and basin architecture of the Trail O region: a record of polyphaser rifting of the east Greenland continental margin. Geosphere 13, 733-70

Passey, S. \& Hitchen, K. 2011. Cenozoic (igneous). In Ritchie, J. D. Ziska, H., Johnson, H. \& Evans, D. (eds) Geology of the FaroeShetland Basin and adjacent areas, 209-28. British Geological Survey, Nottingham, UK. 317 pp (RR/11/001).

Passey, S. \& Jolley, D. W. 2009. A revised lithostratigraphic nomenclature for the Faroe Islands Basalt Group, NE Atlantic Ocean. Transaction of the Royal Society of Edinburgh, Earth and Environmental Science 99, $127-58$

Peck, R. M. 1973. Pollen budget studies in a small Yorkshire catchment. In Birks, H. J. B. \& West, R. G. (eds) Quaternary plant ecology, 4360. Oxford: Blackwells Scientific Publication. 
Planke, S. 1994. Geophysical response of flood basalts from analysis of wire line logs: ocean drilling program site 642 , Vøring volcanic margin. Journal of Geophysical Research: Solid Earth 99, 9279-96.

Planke, S., Alvestad, E. \& Eldholm, O. 1999. Seismic characteristics of basaltic extrusive and intrusive rocks. The Leading Edge 18, 342-48.

Poppitt, S., Duncan, L. J., Preu, B., Fazzari, F. \& Archer, J. 2018. The influence of volcanic rocks on the characterization of the Rosebank Field new insights from ocean-bottom seismic data and geological analogues integrated through interpretation and modelling. In Bowman, M. \& Lyell, B. (eds) Petroleum geology of NW Europe: 50 years of learning, 373-84. Proceedings of the 8th Petroleum Geology Conference. London: Geological Society.

Posamentier, H. W. \& Vail, P. R. 1988. Eustatic control on clastic deposition II - sequence and systems tracts models. In Wilgus, C. K. et al. (eds) Sea level changes: an integrated approach, 125-54. SEPM Special Publication 42. Broken Arrow, Oklahoma, USA: SEPM Society for Sedimentology.

Powell, A. J. 1992. Dinoflagellate cysts of the tertiary system. In Powell, A. J. (ed.) A stratigraphic index of dinoflagellate cysts, 155-251. London: Chapman \& Hall.

Rateau, R., Schofield, N \& Smith, M. 2013. The potential role of igneous intrusions on hydrocarbon migration, West of Shetland. Petroleum Geoscience 19, 259-72.

Ritchie, J. D., Ziska, H., Johnson, H. \& Evans, D. 2011. Geology of the Faroe-Shetland Basin and adjacent areas. Nottingham, UK: British Geological Survey, 317 (RR/11/001).

Rohrman, M. 2007. Prospectivity of volcanic basins: trap delineation and acreage de-risking. AAPG bulletin 91, 915-39.

Saunders, A. D., Fitton, J. G., Kerr, A. C., Norry, M. J. \& Kent, R. W. 1997. The North Atlantic igneous province. In Maoney, J. J. \& Coffin, M. F. (eds) Large igneous provinces: continental, oceanic and planetary flood volcanism, 45-93. Geophysical Monograph 100. Wasington DC, USA: American Geophysical Union.

Schofield, N., Holford, S., Millet, J., Brown, D., Jolley, D., Passey, S. R., Muirhead, D., Grove, C., Magee, C., Murray, J., Hole, M., Jackson, C. A.-L. \& Stevenson, C. 2015. Regional magma plumbing and emplacement mechanisms of the Faroe-Shetland Sill Complex: implications for magma transport and petroleum systems within sedimentary basins. Basin Research 1-23. doi:10.1111/bre.12164

Schofield, N., Jolley, D., Holford, S., Archer, S., Watson, D., Hartley, A., Howell, J., Muirhead, D., Underhill, J. \& Green, P. 2018. Challenges of future exploration within the UK Rockall Basin. Petroleum Geology Conference Proceedings 8, 211-29.

Schofield, N. \& Jolley, D. W. 2013. Development of intra-basaltic lavafield drainage systems within the Faroe-Shetland Basin. Petroleum Geoscience 19, 273-88.

Schroder, T. 1992. A palynological zonation for the Paleocene of the North Sea Basin. Journal of Micropalaeontology 11, 113-26.

Shaw Champion, M. E., White, N. J., Jones, S. M. \& Lovell, J. P. B. 2008. Quantifying transient mantle convective uplift: an example from the Faroe-Shetland Basin. Tectonics 27, TC1002. doi:10.129/ 2007TC002106.

Siegberg, M., Gernon, T. M., Bull, J. M., Keir, D., Barfod, D. N., Taylor, R. N., Abebe, B. \& Ayele, A. 2017. Geological evolution of the Boset-Bericha Volcanic Complex, Main Ethiopian Rift: 40 Ar/ 39 Ar evidence for episodic Pleistocene to Holocene volcanism. Journal of Volcanology and Geothermal Research 351, 115-33.
Smallwood, J. R. \& Gill, C. E. 2002. The rise and fall of the FaroeShetland Basin: evidence from seismic mapping of the Balder Formation. Journal of the Geological Society 159, 627-30.

Sørensen, A. B. 2003. Cenozoic basin development and stratigraphy of the Faroes area. 2003. Petroleum Geoscience 9, 189-207.

Stoker, M., Hollford, S. P. \& Hillis, R. R. 2017. A rift-to-drift record of vertical crustal motions in the Faroe-Shetland Basin, NW European margin: establishing constraints on NE Atlantic evolution. Journal of the Geological Society, London, 175, 263-74.

Stoker, M. \& Varming, T. 2011. Cenozoic (sedimentary). In Ritchie, J., Ziska, H., Johnson, H. \& Evans, D. (eds) Geology of the FaroeShetland Basin and adjacent areas. British Geological Survey. Hawthornes, Nottingham, 152-208.

Storey, M., Duncan, R. A. \& Tegner, C. 2007. Timing and duration of volcanism in the North Atlantic Igneous Province: implications for geodynamics and links to the Iceland hotspot. Chemical Geology 241, 264-81.

Storme, J.-Y., Devleeschouwer, X., Schnyder, J., Cambier, G., Baceta, J. I., Pujalte, V., Di Matteo, A., Lacumin, P. \& Yans, J. 2012. The Palaeocene/Eocene Boundary Section at Zumaia (BasqueCantabric Basin) revisited: new insights from high-resolution magnetic susceptibility and carbon isotope chemostratigraphy on organic matter $\left(\Delta^{13} \mathrm{C}_{\text {org }}\right)$ : the Palaeocene/Eocene boundary section. Terra Nova 24, 310-17.

Troll, V. R., Nicoll, G. R., Donaldson, C. H. \& Emeleus H. 2008. Dating the onset of volcanism at the Rum Igneous Centre, NW Scotland. Journal of the Geological Society, London 165, 651-59.

Vieira, M., Mahdi, S. \& Alderson, A. 2020. New Selandian species of Glaphyrocysta And Spinidinium from offshore Northwest Europe. Review of Palaeobotany and Palynology 275. doi:10.1016/ j.revpalbo.2020.104170/0034-6667.

Waagstein, R., Guise, P. \& Rex, D. 2002. K/Ar and 39Ar/40Ar wholerock dating of zeolite facies metamorphosed flood basalts: the upper Paleocene basalts of the Faroe Islands, NE Atlantic. In Jolley, D. W. \& Bell, B. R. (eds) The North Atlantic igneous province: stratigraphy tectonic, volcanic and magmatic processes, 219-52. London: Geological Society, London, Special Publications 197.

Watson, D., Schofield, N., Jolley, D., Archer, S., Finlay, A. J., Mark, N., Hardman, J. \& Watton, T. 2017. Stratigraphic overview of Palaeogene tuffs in the Faroe-Shetland Basin, NE Atlantic Margin. Journal of the Geological Society, 20pp. doi:10.1144/jgs2016-132.

Wilkinson, C. M., Ganerød, M., Hendricks, B. W. H. \& Eide, E. A. 2017. Compilation and appraisal of geochronological data from the North Atlantic Igneous Province (NAIP). In Peron-Pinvidic, G., Hopper, J. R., Stoker, M.S., Gaina, C., Doornanbal, J. C., Funck, T. \& Arting, U. E. (eds) The NE Atlantic region: reappraisal of crustal structure, tectonostratigraphy and magmatic evolution, 69-103. London: Geological Society of London, Special Publication 447.

Wilson, R. L., Dagley, P. \& Ade-Hall, J. M. 1972. Palaeomagnetism of the British Tertiary Igneous Province: the Skye lavas. Geophysical Journal of the Royal Astronomical Society 28, 285-93.

Wright, K. A., Davies, R. J., Jerram, D. A., Morris, J. \& Fletcher, R. 2012. Applications of seismic and sequence stratigraphic concepts to a lava fed delta system in the Faroe-Shetland Basin, UK and Faroes. Basin Research 24, 91-106. 